\title{
Mathiasite-loveringite and priderite in mantle xenoliths from the Alto Paranaíba Igneous Province, Brazil: genesis and constraints on mantle metasomatism
}

Topical issue

\author{
Vidyã V. Almeida ${ }^{1,2 *}$, Valdecir de A. Janasi², Darcy P. Svisero², Felix Nannini ${ }^{2,3}$ \\ 1 Geological Survey of Brazil (CPRM, SUREG SP), Rua Costa, 55, CEP 01304-010, São Paulo, SP, Brazil \\ 2 Departamento de Mineralogia e Geotectônica, Instituto de Geociências, Universidade de São Paulo, Rua do Lago, 562, CEP \\ 05508-080, São Paulo, SP, Brazil \\ 3 Geological Survey of Brazil (CPRM, SUREG RE), Av. Sul, 2291, CEP 50770-011, Recife, PE, Brazil
}

Received 01 April 2014; accepted 05 July2014

\begin{abstract}
Alkali-bearing Ti oxides were identified in mantle xenoliths enclosed in kimberlite-like rocks from Limeira 1 alkaline intrusion from the Alto Paranaíba Igneous Province, southeastern Brazil. The metasomatic mineral assemblages include mathiasite-loveringite and priderite associated with clinopyroxene, phlogopite, ilmenite and rutile. Mathiasite-loveringite (55-60 wt.\% $\mathrm{TiO}_{2} ; 5.2-6.7 \mathrm{wt} . \% \mathrm{ZrO}_{2}$ ) occurs in peridotite xenoliths rimming chromite ( 50 wt.\% $\left.\mathrm{Cr}_{2} \mathrm{O}_{3}\right)$ and subordinate ilmenite (12-13.4 wt.\% $\mathrm{MgO}$ ) in double reaction rim coronas. Priderite $(\mathrm{Ba} /(\mathrm{K}+\mathrm{Ba})<0.05)$ occurs in phlogopite-rich xenoliths as lamellae within Mg-ilmenite $(8.4-9.8 \mathrm{wt} . \% \mathrm{MgO})$ or as intergrowths in rutile crystals that may be included in sagenitic phlogopite. Mathiasite-loveringite was formed by reaction of peridotite primary minerals with alkaline melts. The priderite was formed by reaction of peridotite minerals with ultrapotassic melts. Disequilibrium textures and chemical zoning of associated minerals suggest that the metasomatic reactions responsible for the formation of the alkali-bearing Ti oxides took place shortly prior the entrainment of the xenoliths in the host magma, and is not connected to old (Proterozoic) mantle enrichment events.

Keywords: crichtonite mineral series $\bullet$ hollandite supergroup $\cdot$ alkali-bearing Ti oxides $\bullet$ mantle xenoliths $\bullet$ lithospheric mantle metasomatism

(c) Versita sp. z o.o.
\end{abstract}

\section{Introduction}

Alkali-bearing $\mathrm{Ti}$ oxides are important reservoirs of silicate-incompatible elements in the subcontinental lithospheric mantle, and may make an important

*E-mail: vidya.almeida@cprm.gov.br contribution to the budget of these elements in metasomatized peridotites, with implications for the modeling of trace element fractionation between mantle rocks and melts, even when present in small amounts [13]. They appear to be generated over a wide pressure interval, as indicated by experimental studies which show the coexistence of priderite, lindsleyite-mathiasite (crichtonite series) and hawthorneite-yimengite series minerals with diamond $[1,4,5]$. The high concentrations 
of large ion lithophile elements (LILE) and high field strength elements (HFSE), coupled with their stability at high pressure, connect these minerals with the source regions of mantle-derived alkaline magmas [3]. Some alkaline $\mathrm{Ti}$-oxides such as priderite and K-triskaidecatitanates are typomorphic minerals of lamproite [6] and orangeite [7], respectively, and their presence has important petrological implications.

This work documents the first recognition of mathiasite in South America and also describes priderite and associated mineral phases (phlogopite, clinopyroxene, ilmenite and rutile) found in xenoliths enclosed in the Limeira 1 alkaline intrusion in the Alto Paranaíba Igneous Province (APIP), Brazil. Lindsleyite-mathiasite is compositionally related to priderite and armalcolite and its origin in depleted peridotite xenoliths is related to reactions of an incompatible-element enriched melt with $\mathrm{Cr}$-rich spinel $[8,9]$. The known occurrences of mathiasite are concentrated in kimberlites from South Africa (e.g., Jagersfontein, Kolonkwanen) [9] and in the Shandong Province, China [10], while priderite is commonly found in lamproites and rare ultramafic xenoliths such as those from the Prairie Creek, Arkansas, USA [11, 12].

In spite of the importance of these rare $\mathrm{Ti}$ oxides there are few works focusing the processes and reactions that lead to their formation in natural occurrences with details of their textural relationships. Therefore, their study may help understand the geological processes and reactions involved in their formation, with implications for the evolution of the lithospheric mantle in SE Brazil.

\section{Geological setting}

The APIP (Figure 1(a)) is recognized as one of the largest mafic-potassic igneous provinces in the world [13-15]. The province is located next to the northeastern border of the Phanerozoic Paraná Sedimentary Basin and intrudes meta-supracrustal rocks from the Neoproterozoic Brasília Fold Belt near the southwestern tip of the ArcheanPaleoproterozoic São Francisco Craton (Figure 1(a)). The lavas and tuffs from the Mata da Corda Formation are the most voluminous manifestation of the mafic-potassic magmatism in the province (Figure 1(b)). Kimberlites and related rocks from the Coromandel region and neighboring areas have ages between 90 and $80 \mathrm{Ma}[13,16]$. Recent gravimetric and isotopic studies indicate that the São Francisco Craton lithosphere underlies the Brasília Fold Belt in this region $[14,15,17,18]$. Remarkable effects of changes in the lithosphere in areas affected by the Cretaceous alkaline magmatism have been identified by several geophysical tools. Of particular relevance, a significant low velocity anomaly of $P$ and $S$ seismic waves was identified in the northeastern border of Paraná Basin, where it forms a vertical cylinder in the upper mantle. This was initially interpreted as a fossil plume [19], but later work suggested that it had a chemical rather than thermal origin [20].

The enriched character of the APIP alkaline magmas is considered to reflect mantle sources affected by metasomatism during the Meso and Neoproterozoic magmatism in the Brasília Fold Belt, resulting in a veined lithospheric mantle rich in pyroxene, phlogopite, amphibole, carbonate, phosphate and $\mathrm{Ti}$ oxides [15]. However, there is evidence of Cretaceous metasomatism in the lithosphere beneath the APIP, in view of the contrasts between the mantle signature sampled by Lower Cretaceous diamond-bearing kimberlites (e.g., the $\sim 120$ Ma Canastra 01 kimberlite) and that shown by the Upper Cretaceous kamafugites (Mata da Corda volcanism) [17].

\subsection{The Limeira kimberlite}

The Limeira ultramafic alkaline plugs (Figure 1(b)) are located near the town of Monte Carmelo, state of Minas Gerais, southeastern Brazil, and consist of two separate small bodies intruding Neoproterozoic granites. The Limeira 1 intrusion, with a diameter of $200 \mathrm{~m}$, is made up of a dark grey kimberlite [16, 21-23] with a seriate texture, where macrocrysts of olivine and phenocrysts/microphenocrysts of olivine, phlogopite, spinel (often mantled by perovskite) and calcite are set in a microcrystalline groundmass with olivine, monticellite, magnetite, ilmenite, perovskite, serpentine, apatite and carbonates [16]. LA-ICPMS U-Pb dating of perovskite yielded an age of $91 \pm 6 \mathrm{Ma}$, at the upper limit of the estimated age range of the Upper Cretaceous magmatism in the APIP [16]. Limeira 2 (Figure 1(b)) is a smaller satellite plug with $75 \mathrm{~m}$ diameter made up of a finegrained alkaline ultramafic rock [23] which differs from Limeira 1 both mineralogically (e.g., showing groundmass clinopyroxene and Ti-rich phlogopite) and chemically (higher $\mathrm{SiO}_{2}, \mathrm{Al}_{2} \mathrm{O}_{3}$ and alkalis, lower $\mathrm{MgO}$ ). Both Limeira 1 and Limeira 2 have similar unradiogenic $\mathrm{Nd}$ isotope signature $\left(\varepsilon \mathrm{Nd}_{\mathrm{T}} \sim-5.5\right)$; the Limeira $2 \mathrm{Sr}$ isotope signature is slightly more radiogenic $\left({ }^{87} \mathrm{Sr} /{ }^{86} \mathrm{Sr}_{\mathrm{T}}=0.7062\right.$ versus 0.7052 in Limeira 1) [23].

Mantle xenoliths from Limeira 1 are up to $15 \mathrm{~cm}$ large, and composed of spinel-bearing dunite, harzburgite and lherzolite with protogranular and transitional textures sensu [24], with subordinate glimmerite. Temperatures up to $850^{\circ} \mathrm{C}$ were estimated in Limeira 1 peridotite xenoliths [22]. 

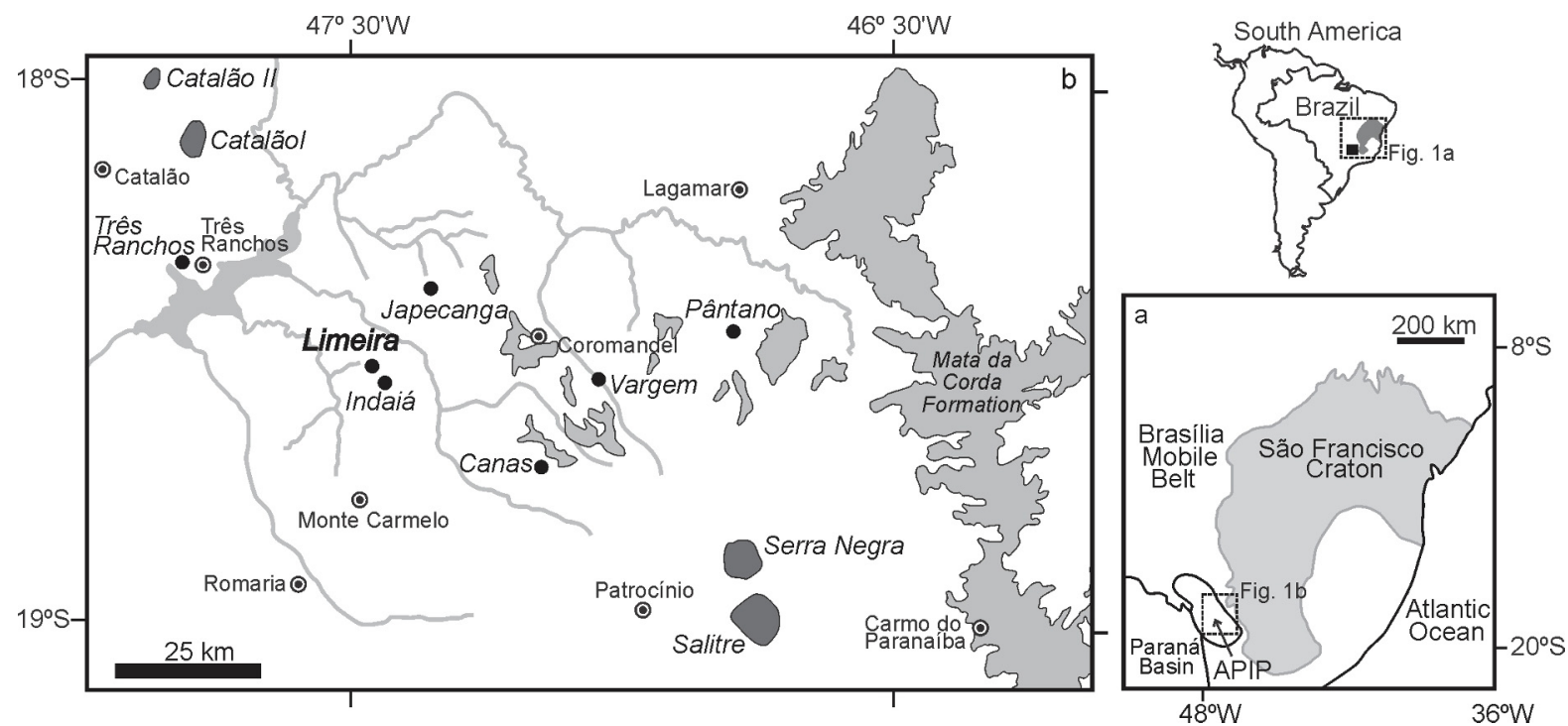

Figure 1. (a) Locality map of the São Francisco Craton showing the Brasília Mobile Belt and its relation with the Alto Paranaíba Igneous Province (modified from [48]). (b) Locality map of the Alto Paranaíba Igneous Province showing the Limeira and other alkaline intrusions (black circles), carbonatitic complexes (dark grey) and the Mata da Corda Formation (light grey).

\section{Analytical techniques}

Major elements in minerals were analyzed in a JEOL JXA-8600 electron microprobe at the Geoanalitica Core Facility, Instituto de Geociências, Universidade de São Paulo, Brazil. Analyses were performed at $15 \mathrm{kV}$ acceleration voltage and $20 \mathrm{nA}$ beam current; beam diameter was normally $5 \mu \mathrm{m}$; a $10 \mu \mathrm{m}$ diameter was used in crystals with tiny lamellae previously identified in backscattered electron (BSE) images. Standards were natural and synthetic minerals: standards used in the mathiasite-loveringite and priderite analyses include metallic $\mathrm{Nb}(\mathrm{Nb})$, wollastonite $(\mathrm{Si}, \mathrm{Ca})$, rutile $(\mathrm{Ti})$, metallic $\mathrm{Zr}(\mathrm{Zr})$, anorthite $(\mathrm{Al}), \mathrm{Cr}_{2} \mathrm{O}_{3}(\mathrm{Cr})$, diopside $(\mathrm{Mg})$, olivine (Mn, Fe), Sr silicate (SRAN) (Sr), natural Ba silicate (Ba), albite ( $\mathrm{Na})$, asbest $(\mathrm{K})$ and REE3 glass (La, Ce). Corrections were performed using the PROZA procedure [25]. BSE images of the alkali-titanates were performed using the LEO 440I scanning electron microscope at Instituto de Geociências, Universidade de São Paulo. Trace element analyses in clinopyroxene were performed by LA-Q-ICP-MS at the Geoanalitica Core Facility, Instituto de Geociências, Universidade de São Paulo, using a Parkin-Elmer ELAN-600 quadrupole ICPMS with a $216 \mathrm{~nm} \mathrm{Nd}$-YAG New-Wave laser ablation system, with a spatial resolution of 20-40 $\mu \mathrm{m}$. NIST 610 glass was used as a calibration standard and the concentration of $\mathrm{Ca}$ from the electron microprobe analyses was used as internal standard.

\section{Mathiasite-loveringite}

Lindsleyite, mathiasite and loveringite are titanates of the crichtonite group (general formula $\mathrm{AM}_{21} \mathrm{O}_{38}$ ) whose nomenclature is defined by the occupancy of the large 12-coordination $\mathrm{A}$ site $\left(\mathrm{Ba}^{2+}\right.$ in lindsleyite, $\mathrm{K}^{+}$in mathiasite and $\mathrm{Ca}^{2+}$ in loveringite). Lindsleyite and mathiasite were originally identified in metasomatized peridotites and mineral concentrates from South African kimberlites (De Beers, Bultfontein, Kolonkwanen and Jagersfontein; $[9,26]$ where they are characteristically associated with phlogopite, diopside, K-richterite, Nb$\mathrm{Cr}$ rutile, $\mathrm{Mg}-\mathrm{Cr}-\mathrm{Nb}$ ilmenite and $\mathrm{Mg}-\mathrm{Cr}$ spinel. Other reported occurrences of these minerals are rare, and include lindsleyite-mathiasite found in kimberlites from China [27]. Loveringite is reported as a late-stage (intercumulus) mineral in mafic intrusions [28], but was also reported to coexist with lindsleyite-mathiasite in kimberlite [29].

\subsection{Textural relationships}

A titanate from the mathiasite-loveringite series was identified in a metasomatized protogranular harzburgite 
xenolith (sample \#2) from the Limeira 1 kimberlite as a component of double reaction rim coronas.

This harzburgite xenolith consists of a framework of $\leq$ $6 \mathrm{~mm}$ anhedral olivine showing undulatory extinction and subordinate $\leq 2 \mathrm{~mm}$ light-brown anhedral orthopyroxene. Aggregates of very fine-grained olivine neoblasts (10$20 \mu \mathrm{m}$ ) are developed along the rims and microfractures of most olivine crystals. Minor clinopyroxene occurs as small vein-like grains in cracks of orthopyroxene (Figure 2(a)(c)) or as interstitial grains that surround rounded olivine grains (Figure 2(d)).

Phlogopite occurs as $\sim 0.3-0.6 \mathrm{~mm}$ deformed grains in double reaction rim coronas where chromite is concentrated at the inner zone and clinopyroxene at the outer zone of the corona (Figure 3(a)-(d)). A skeletal ilmenite grain with abundant $\mathrm{Cr}$-rich exsolution lamellae parallel to (0001) is associated with chromite (Figure 3(d), (f)). Mathiasite-loveringite was identified by BSE images in sample \#2 as reaction rims up to $0.1 \mathrm{~mm}$ thick around chromite (Figure 3(b)) and ilmenite (Figure 3(d)) from the inner zone of the coronas. When in contact with the host rock, it develops a reaction rim where it is intergrown with perovskite (Figure 3(d)-(e)).

\subsection{Mineral compositions}

Representative compositions of the main minerals of the harzburgite xenolith (sample \#2) are presented in Table 1. Olivine and the pyroxenes are $\mathrm{Mg}$-rich $\left(\mathrm{Fo}_{88-89}\right.$; opx $\mathrm{Mg} \#=90 ;$ cpx Mg\#=90-94), and both pyroxenes show very low $\mathrm{Al}_{2} \mathrm{O}_{3}$ contents ( $\sim 0.3-0.4 \%$ in cpx; $\sim 0.8 \%$ in opx), consistent with a melt-depleted nature for this xenolith. Analyses of olivine and pyroxenes from a representative phlogopite-free harzburgite xenolith from the Limeira 1 kimberlite (sample \#1) are presented in Table 2 for comparison. The $\mathrm{Al}_{2} \mathrm{O}_{3}$ contents of pyroxenes from sample \#1 are remarkably higher $(2.4-2.5 \%$ in opx; 2.3-3.5\% in (px), whereas the $\mathrm{Mg} \#$ of all its mafic minerals is also higher ( $\mathrm{Fo}_{92}$; opx $\mathrm{Mg} \#=92 ;$ сpx $\left.\mathrm{Mg} \#=95\right)$ when compared to sample \#2. The lower $\mathrm{Mg \#}$ coupled with comparatively high $\mathrm{TiO}_{2}$ contents of the pyroxenes from the phlogopite (and titanate)-bearing sample \#2 (Table 1) may be an indicator that the whole xenolith was enriched in $\mathrm{Fe}$ and $\mathrm{Ti}$ by cryptic metasomatism. An equilibration temperature of $921^{\circ} \mathrm{C}$ was estimated for sample \#1 using the $\mathrm{Al}$ in opx method [30].

Phlogopite from sample \#2 has low $\mathrm{Al}_{2} \mathrm{O}_{3}$ (11.9-12.4 wt.\%), resulting in a slight deficiency in the tetrahedral site (Table 2), and moderate $\mathrm{TiO}_{2}$ contents (2.4-3.0 wt.\%). This composition plots in the field of MARID (mica-amphibolerutile-ilmenite-diopside xenoliths, [31]) and kimberlite micas in the diagram (Figure 4(a)). The composition of phlogopite megacrysts from other alkaline intrusions of the APIP show even lower $\mathrm{Al}_{2} \mathrm{O}_{3}$ contents (Figure 4(a)).

Spinel from sample \#2 is a Ti-rich chromite (49.8 wt.\% $\mathrm{Cr}_{2} \mathrm{O}_{3} ; 5$ wt.\% $\mathrm{TiO}_{2}$ ) whereas that in sample \#1 has much lower $\mathrm{Cr}_{2} \mathrm{O}_{3}$ (up to 29.7 wt.\%). Ilmenite has remarkably high contents of $\mathrm{MgO}$ (12-13.4 wt.\%) and $\mathrm{Cr}_{2} \mathrm{O}_{3}$ (8.6-9.2 wt.\%), which overlaps the composition of some ilmenite megacrysts reported in the Limeira 1 kimberlite ( [32]; Figure 4(b)). The compositions are located close to the Mg-rich arm of the "mantle ilmenite parabola" [33], but at higher $\mathrm{Cr}$ contents (Figure 4(b)).

Trace-element microanalysis of clinopyroxene from sample \#2 by LA-ICPMS (Table 3) reveal fractionated REE patterns $\left(\mathrm{La}_{N} / \mathrm{Yb}_{N}\right.$ up to 10$)$ that are convex-upward at the LREE portion $\left(\mathrm{La}_{N} / \mathrm{Nd}_{N}<1\right)$ (Figure $\left.5(\mathrm{a})\right)$. This clinopyroxene is enriched in several other incompatible trace-elements (e.g., 10x primitive mantle contents of $\mathrm{Zr}, \mathrm{Sr}, \mathrm{Pb}, \mathrm{Ba})$, but alone it cannot account for the enrichment of elements more incompatible than $\mathrm{Pr}$ in the host harzburgite (Figure 5(b)), requiring the presence of another phase hosting these elements.

Representative compositions of mathiasite-loveringite are shown in Table 4, and reveal that this is the phase that accommodates most of the incompatible elements not contained in clinopyroxene (e.g., LREE, Ba, Nb, Zr); Th, $\mathrm{U}, \mathrm{Pb}$ and $\mathrm{Rb}$, were not analysed but may also reside in mathiasite-loveringite. It must be stressed, however, that part of these elements may also reside in tiny crystals of secondary perovskite formed by reaction of the xenolith with the host melt, so a small part of the whole rock enrichment in incompatible elements might reflect infiltration of fluids/melts from the host kimberlite (cf. trace-element patterns of the latter in Figure 5(a),(b)).

The analyses obtained in three different crystals rimming ilmenite and chromite (see location of spots in Figure 3(b), (d)) are reported in Table 4 . Six results spread beyond a cluster defined by the other 12 showing high and variable contents of $\mathrm{K}$, which are accompanied by increases in $\mathrm{Ba}$ and $\mathrm{Na}$ and compensated by a decrease in Fe (Figure 6). Close inspection of BSE images (Fig. 3b,d) shows that both the internal and external borders of the titanate show evidence of alteration, and these results probably correspond to mixtures with small amounts of unidentified alkali-rich phase(s); these analyses are therefore excluded from the rest of our discussion.

Nomenclature of minerals from the crichtonite series is based on the occupancy of the 12-coordinated $A$ site (Ba: lindsleyite, $\mathrm{K}$ : mathiasite, $\mathrm{Ca}$ : loveringite, Sr: crichtonite, $\mathrm{Na}$ : landauite, $\mathrm{Pb}$ : senaite, U+ETR: davidite). Total A-site occupancy in our typical analyses is always in excess of 1 (1.01-1.15; average 1.06), which is common in crichtonite minerals in general 

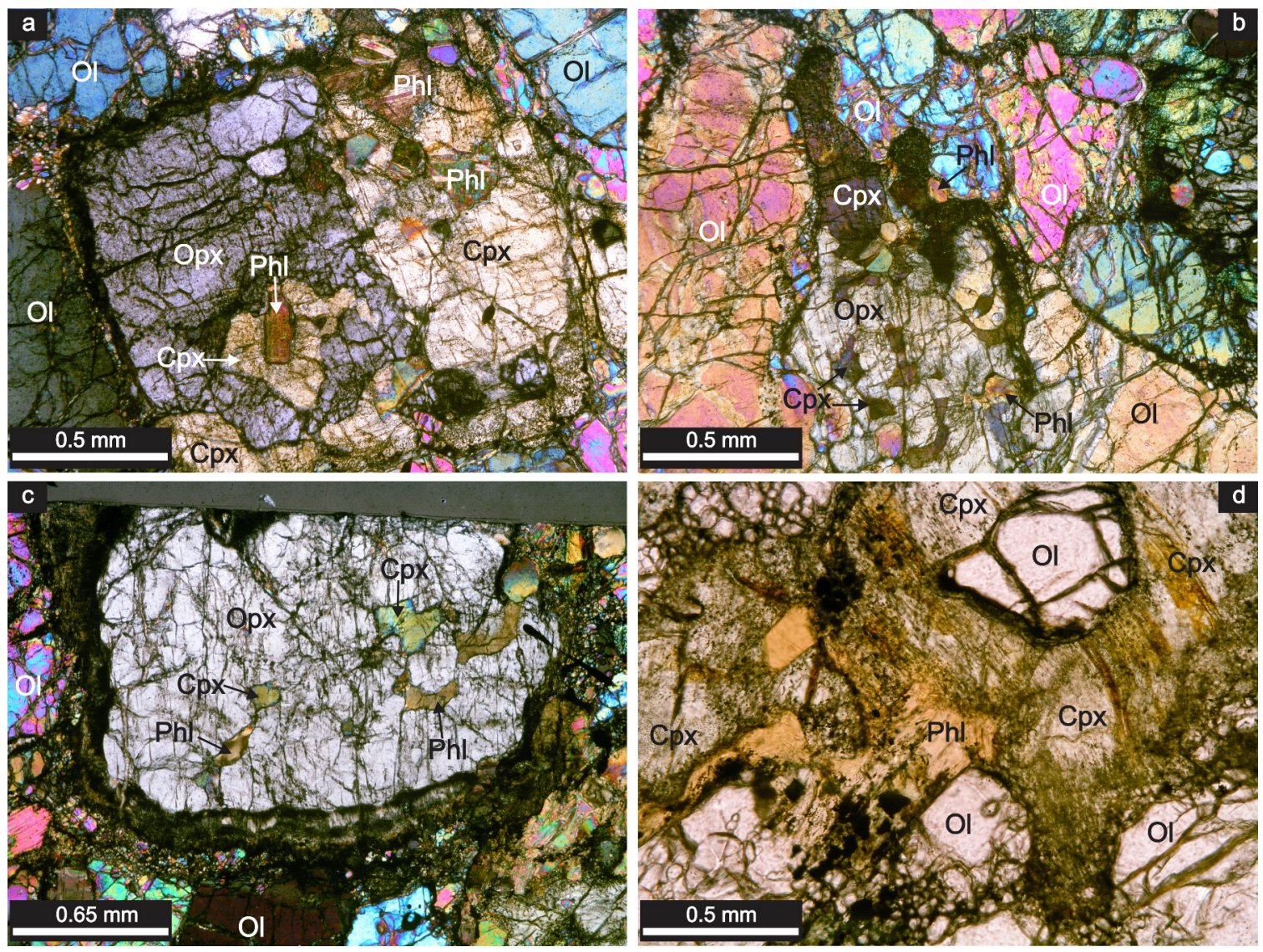

Figure 2. Transmitted-light photomicrographs of representative textures in the xenolith (sample \#2); (a) Contact between orthopyroxene (Opx) and clinopyroxene ( $\mathrm{Cpx}$ ) showing vein-like clinopyroxene along with phlogopite $(\mathrm{Phl})$ in cracks of orthopyroxene; (b) Textural relationship between orthopyroxene, olivine (OI) and clinopyroxene showing vein-like clinopyroxene included in orthopyroxene; (c) Vein-like clinopyroxene along with phlogopite in cracks of orthopyroxene; (d) Clinopyroxene surrounding olivine crystals.

and in members of the lindsleyite-mathiasite series [9]. The average $A$ occupancy (in atoms per formula unit) is: $\mathrm{Ca}_{0.46} \mathrm{~K}_{0.33} \mathrm{Sr}_{0.11} \mathrm{Ba}_{0.06} \mathrm{Na}_{0.05} \mathrm{La}+\mathrm{Ce}_{0.06}$ (Table 4). A dominance of $\mathrm{Ca}$ over $\mathrm{K}$ would indicate that the mineral is loveringite, not mathiasite. Plotted in the triangular $\mathrm{Ba}-\mathrm{K}-(\mathrm{Ca}+\mathrm{Sr}+\mathrm{Na}+\mathrm{LREE}+\mathrm{Pb})$ diagram of [9] (Figure 7), our analyses overlap the most Ca-rich compositions of mathiasites from Jagersfontein, reinforcing the suggestion that there is a continuous solid solution between mathiasite and loveringite. We therefore chose to use the name mathiasite-loveringite for our species. The crystallochemical behavior of $\mathrm{Ca}$ in the crichtonite series is known to be distinct from the other large cations, so that in some species it may be partly located in smaller (8-coordinated) sites [34].

Refinements of the structures of chrichtonite-series minerals show that their formula is better expressed as $A B C_{18} T_{2} \mathrm{O}_{38}$ : the " $M$ " site of the generic formula $\mathrm{AM}_{21} \mathrm{O}_{38}$ corresponds to at least 5 different sites, of which one is tetrahedral $(\mathrm{M} 2=\mathrm{T})$, and accommodates 2 smaller cations ( $\mathrm{Al}, \mathrm{Fe})$ per formula unit, while the remaining are octahedral, but have different sizes and positions. Larger cations ( $\mathrm{Zr}, \mathrm{Mn}$ and part of $\mathrm{Ca}$ ) are accommodated in the larger $\mathrm{M} 1$ (=B; 1 atom per formula unit) while other three octahedral sites (M3, M4 and M5, collectively grouped as C; 18 atoms per formula unit) accommodate $\mathrm{Ti}$ and other cations of intermediate size such as $\mathrm{Mg}, \mathrm{Fe}^{2+}, \mathrm{Cr}, \mathrm{Nb}$ and $\mathrm{V}$ [34]. Refinement of the mathiasite structure showed that an additional octahedral site (M6) may be filled with up to 0.2 atoms (of $\mathrm{Mg}$ ) per formula unit [35].

Typical mathiasite-loveringite from sample \#2 averages 59.5 wt.\% $\mathrm{TiO}_{2}, 14.4$ wt.\% $\mathrm{Cr}_{2} \mathrm{O}_{3}, 10.7$ wt.\% $\mathrm{FeO}_{\mathrm{T}}$ and 5.8 wt.\% $\mathrm{ZrO}_{2}$. Totals at the generic "M" sites (excluding $\mathrm{Ca}$ ) are consistently higher than 21 (21.4-21.5, Table 4). A 

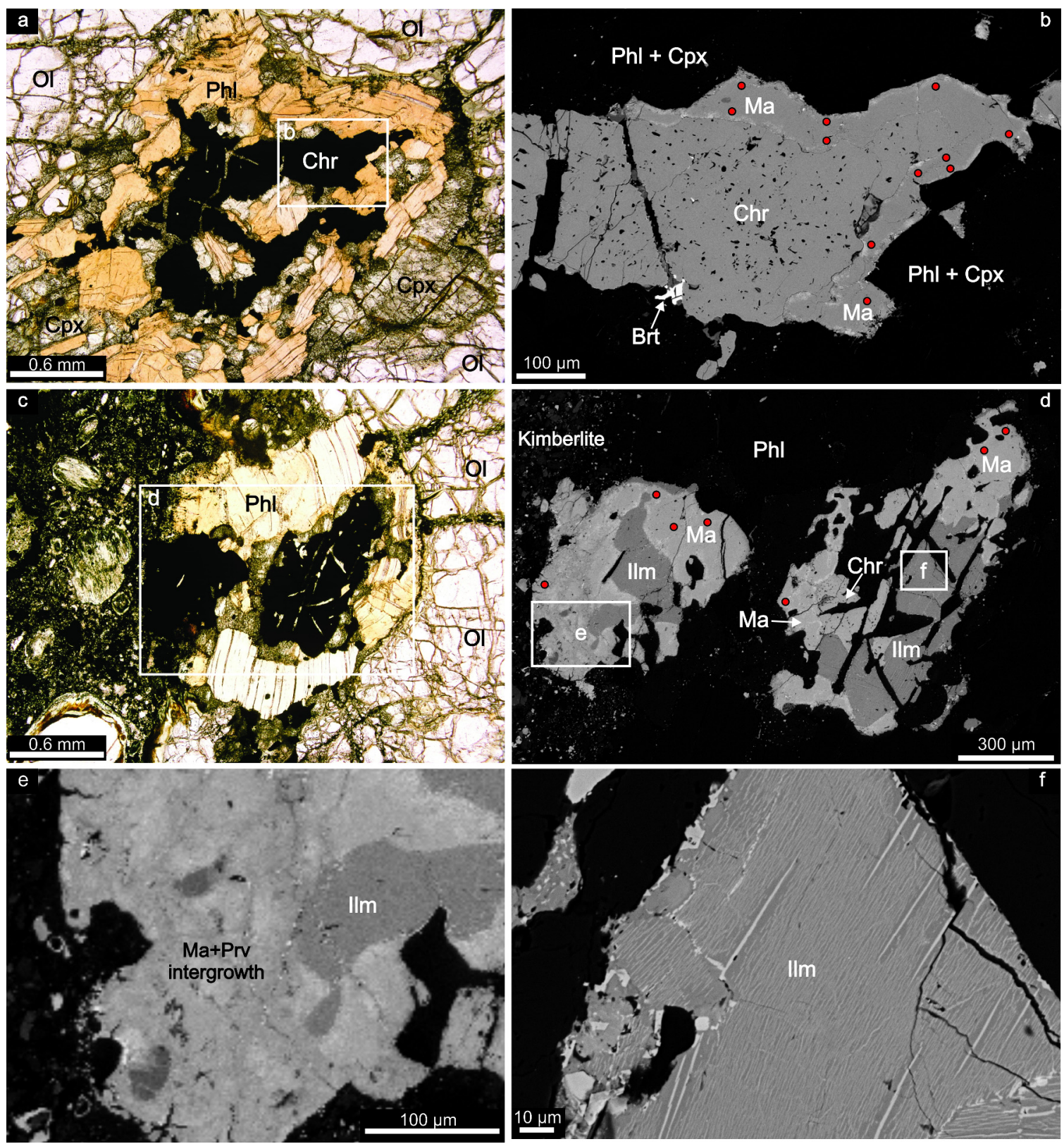

Figure 3. (a) Transmitted-light photomicrograph of double reaction rim corona composed by chromite (Chr) at the inner zone and phlogopite (Phl) and clinopyroxene ( $\mathrm{Cpx}$ ) at the outer zone; (b) BSE image showing the reaction rim corona composed by mathiasite (Ma) enveloping the chromite indicated in (a) Barite (Brt) is observed in microfracture; (c) Transmitted-light photomicrograph of a reaction rim corona located at the contact with the host rock; (d) BSE image of the corona indicated in c showing the mathiasite (Ma) enveloping chromite and ilmenite (IIm); (e) BSE image showing mathiasite-perovskite (Prv) intergrowth at the contact with the host rock; (f) BSE image of the exsolution lamellae in ilmenite crystal.

tentative split between the different $M$ sites (Table 4) yields on average: $\mathrm{T}=2$ apfu $=\mathrm{Al}_{0.27} \mathrm{Si}_{0.01} \mathrm{Fe}_{1.72}, \mathrm{C}=$ 18 apfu $=\mathrm{Ti}_{12.96} \mathrm{Cr}_{3.30} \mathrm{Mg}_{1.40} \mathrm{Nb}_{0.02} \mathrm{Fe}_{0.32}, \mathrm{~B}=\mathrm{Zr}_{0.83} \mathrm{Mn}_{0.02}$ $(\Sigma=0.85$; the remaining 0.15 apfu filled with cations with greater ionic radii, possibly $\mathrm{Fe}^{2+}$ ). Total $\mathrm{Fe}$ is 2.60 apfu, of which only 2.04 ( \pm 0.15 in B) are allocated in the formula above. The $\sim 0.4$ apfu not allocated reflect the bulk excess to the 21 apfu of the ideal formula, and possibly are in 

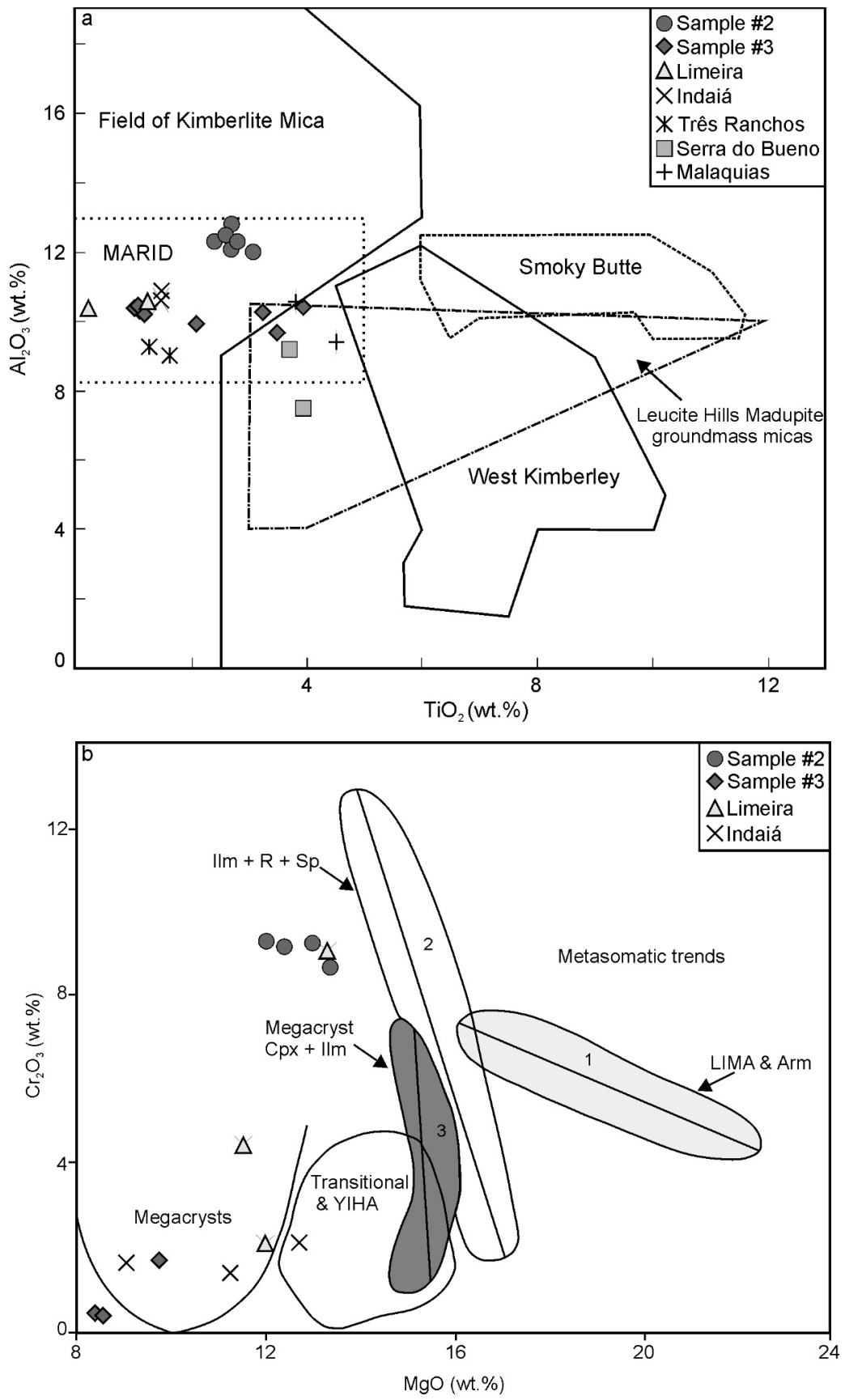

Figure 4. (a) Compositions of phlogopite from samples \#2 and \#3, with fields of phlogopite compositions from kimberlites, lamproites and the MARID xenolith suite [6, 31, 49-51]; (b) IImenite compositions from samples \#2 and \#3 with fields of compositions of ilmenite megacrysts, ilmenite associated with clinopyroxene, rutile + spinel, LIMA (lindsleyite and mathiasite) + Arm (armalcolite) and with YIHA (yimengite and hawthorneite). Modified from [33]. Compositions of phlogopite and ilmenite from Limeira, Indaiá and Três Ranchos kimberlites, Serra do Bueno lamproite and Malachias kamafugite from APIP are shown for comparison [16, 23, 32, 52]. 
Table 1. Representative electron microprobe analyses of minerals from sample \#2.

\begin{tabular}{|c|c|c|c|c|c|c|c|c|c|c|c|c|c|c|c|}
\hline Mineral & $\mathrm{Ol}$ & $\mathrm{Ol}$ & Opx & Opx & Cpx & Cpx & Cpx & Mineral & Chr & $\mathrm{Ilm}$ & $\mathrm{Ilm}$ & Mineral & $\mathrm{Phl}$ & $\mathrm{Phl}$ & $\mathrm{Phl}$ \\
\hline $\mathrm{SiO}_{2}$ & 40.75 & 40.35 & 56.97 & 56.93 & 54.06 & 54.85 & 54.54 & $\mathrm{Nb}_{2} \mathrm{O}_{5}$ & & 0.03 & 0.02 & $\mathrm{SiO}_{2}$ & 41.22 & 40.56 & 40.45 \\
\hline $\mathrm{TiO}_{2}$ & bd. & bd. & 0.25 & 0.25 & 0.32 & 0.34 & 0.36 & $\mathrm{SiO}_{2}$ & & 0.02 & 0.02 & $\mathrm{TiO}_{2}$ & 2.73 & 2.70 & 3.08 \\
\hline $\mathrm{Al}_{2} \mathrm{O}_{3}$ & bd. & 0.02 & 0.32 & 0.37 & 0.85 & 0.79 & 0.81 & $\mathrm{TiO}_{2}$ & 4.74 & 46.32 & 46.65 & $\mathrm{Al}_{2} \mathrm{O}_{3}$ & 12.36 & 12.01 & 11.94 \\
\hline $\mathrm{Cr}_{2} \mathrm{O}_{3}$ & bd. & 0.03 & 0.32 & 0.26 & 1.15 & 1.32 & 1.21 & $\mathrm{ZrO}_{2}$ & & 0.18 & 0.14 & $\mathrm{FeO}$ & 4.81 & 5.04 & 4.47 \\
\hline $\mathrm{FeO}$ & 10.67 & 11.63 & 6.94 & 6.97 & 3.58 & 3.53 & 3.56 & $\mathrm{Al}_{2} \mathrm{O}_{3}$ & 3.51 & 0.29 & 0.23 & $\mathrm{MnO}$ & 0.04 & 0.03 & 0.03 \\
\hline $\mathrm{MnO}$ & 0.11 & 0.19 & 0.18 & 0.19 & 0.11 & 0.10 & 0.13 & $\mathrm{FeO}$ & 21.61 & 30.02 & 29.87 & $\mathrm{MgO}$ & 23.27 & 23.63 & 23.53 \\
\hline $\mathrm{NiO}$ & 0.34 & 0.32 & & & & & & $\mathrm{Fe}_{2} \mathrm{O}_{3}{ }^{*}$ & 10.91 & & & $\mathrm{CaO}$ & 0.02 & 0.07 & 0.00 \\
\hline $\mathrm{MgO}$ & 48.25 & 47.53 & 34.65 & 34.21 & 17.85 & 17.83 & 17.86 & $\mathrm{Cr}_{2} \mathrm{O}_{3}$ & 49.83 & 9.13 & 8.62 & $\mathrm{BaO}$ & 0.03 & 0.13 & 0.01 \\
\hline $\mathrm{CaO}$ & bd. & 0.09 & 0.82 & 0.74 & 20.14 & 19.98 & 20.13 & $\mathrm{MgO}$ & 9.81 & 12.40 & 13.35 & $\mathrm{Na}_{2} \mathrm{O}$ & 0.03 & 0.03 & 0.10 \\
\hline $\mathrm{Na}_{2} \mathrm{O}$ & bd. & 0.01 & 0.10 & 0.10 & 1.10 & 1.02 & 1.11 & $\mathrm{ZnO}$ & 0.16 & 0.11 & 0.07 & $\mathrm{~K}_{2} \mathrm{O}$ & 10.71 & 10.37 & 10.85 \\
\hline $\mathrm{K}_{2} \mathrm{O}$ & bd. & bd. & 0.01 & 0.09 & 0.01 & 0.03 & 0.04 & $\mathrm{MnO}$ & 0.19 & 0.26 & 0.30 & Total & 95.22 & 94.57 & 94.46 \\
\hline Total & 100.12 & 100.16 & 100.56 & 100.11 & 99.17 & 99.79 & 99.75 & $\mathrm{CaO}$ & & 0.08 & 0.08 & $\mathrm{~F}$ & 0.35 & 0.58 & 0.55 \\
\hline Fo & 89 & 88 & & & & & & Total & 100.76 & 98.84 & 99.35 & $\mathrm{Cl}$ & 0.00 & 0.00 & 0.02 \\
\hline \multirow[t]{5}{*}{$\mathrm{Mg} \#$} & & & 89.9 & 89.8 & 93.9 & 90.0 & 92.7 & $\mathrm{FeOI}$ & 31.42 & & & $\mathrm{Si}$ & 5.89 & 5.85 & 5.84 \\
\hline & & & & & & & & $\mathrm{Cr} \#$ & 90.5 & & & Al IV & 2.08 & 2.04 & 2.03 \\
\hline & & & & & & & & & & & & Al VI & 0.00 & 0.00 & 0.00 \\
\hline & & & & & & & & & & & & Total IV & 7.97 & 7.88 & 7.86 \\
\hline & & & & & & & & & & & & Mg\# & 90 & 89 & 90 \\
\hline
\end{tabular}

"calculated using the procedure of [56]; $\mathrm{Mg} \#=100^{*}(\mathrm{Mg}) /(\mathrm{Mg}+\mathrm{Fe}) ; \mathrm{Cr} \#=100 *(\mathrm{Cr}) /(\mathrm{Cr}+\mathrm{Al})$;

cationic proportions in phlogopite calculated on the basis of $22 \mathrm{O}$

bd.= below detection limit

part accommodated in partially filled site M6 (occupied by $\mathrm{Mg}$; [35]). According to [3] the excess usually observed in the $A$ and $M$ sites in natural crichtonite would be related to the capacity of their mineral structures to contain a significant amount of vacancies.

A significant feature of the studied titanate is its $\mathrm{Cr}$ and $\mathrm{Zr}$-rich composition; high $\mathrm{Cr}_{2} \mathrm{O}_{3}$ contents, in particular, are characteristic of mathiasite and lindsleyite (1218 wt.\%). These are higher than typical contents of loveringite ( 6 wt.\%; [9]); however, up to 12 wt.\% $\mathrm{Cr}_{2} \mathrm{O}_{3}$ was reported for loveringite from bronzite cumulate layers in the Jimberlana intrusion, Australia [28].

\section{Priderite}

Priderite is a titanate of the hollandite supergroup with an ideal chemical formula $\mathrm{K}\left(\mathrm{Ti}_{7}^{4+} \mathrm{Fe}^{3+}\right) \mathrm{O}_{16}$ where $\mathrm{K}^{+}$in the larger $\mathrm{A}$ site may be replaced by other monovalent $(\mathrm{Na})$ and bivalent ( $\mathrm{Ba}, \mathrm{Sr}, \mathrm{Pb})$ cations [36] and trivalent $\mathrm{Fe}$ in the $\mathrm{M}$ site may be replaced by $\mathrm{Cr}$ and $\mathrm{V}$. Priderite was first described by [37], and is commonly found in leucite lamproites and also in mantle xenoliths such as those from
Prairie Creek mica peridotite from Arkansas, USA [11, 12] In Brazil, it was previously described only in phlogopitites from the Catalão Carbonatitic Complex in the APIP [38].

\subsection{Textural relationships}

The priderite-bearing sample (sample \#3) from the Limeira 1 kimberlite is a peculiar phlogopite-ilmenite rich xenolith which consists of alternating $\mathrm{mm}$-sized bands dominated by: (a) ilmenite plus phlogopite and (b) clinopyroxene plus some phlogopite and olivine relics. Both bands are cut by veinlets of serpentine.

Priderite crystals were identified in sample \#3 in two different textures: (a) as small $(\sim 30 \mu \mathrm{m})$ dark red lensshaped lamellae within the large ilmenite crystals that make up most of the sample (Figure 8(a), (b)), and (b) as patchy zones replacing small rutile crystals, which may or not be included in sagenitic phlogopite (Figure 8(e), $(f))$, and are partially surrounded by a ring of "clean" ilmenite. Both textural types of ilmenite are surrounded and in part infiltrated by intergrowths of perovskite and magnetite (locally also small crystals of barite), which correspond to products of reaction with the host kimberlite. 
Table 2. Representative electron microprobe analyses of minerals from sample \#1.

\begin{tabular}{|c|c|c|c|c|c|c|c|}
\hline Mineral & $\mathrm{Ol}$ & Opx & Opx & Cpx & Cpx & Sp & Sp \\
\hline $\mathrm{SiO}_{2}$ & 40.93 & 56.52 & 56.15 & 52.89 & 53.46 & & \\
\hline $\mathrm{TiO}_{2}$ & bd. & bd. & 0.01 & bd. & 0.06 & bd. & 0.01 \\
\hline $\mathrm{Al}_{2} \mathrm{O}_{3}$ & bd. & 2.45 & 2.67 & 3.45 & 3.32 & 39.98 & 38.90 \\
\hline $\mathrm{Cr}_{2} \mathrm{O}_{3}$ & bd. & 0.41 & 0.46 & 1.09 & 1.08 & 27.80 & 29.71 \\
\hline $\mathrm{FeO}$ & 8.17 & 5.61 & 5.52 & 1.60 & 1.77 & 13.88 & 14.37 \\
\hline $\mathrm{Fe}_{2} \mathrm{O}_{3}{ }^{*}$ & & & & & & 2.45 & 1.54 \\
\hline $\mathrm{MnO}$ & 0.16 & 0.14 & 0.12 & 0.11 & 0.09 & 0.14 & 0.10 \\
\hline $\mathrm{NiO}$ & 0.42 & & & & & & \\
\hline $\mathrm{MgO}$ & 50.40 & 34.91 & 34.97 & 16.14 & 16.49 & 15.78 & 15.49 \\
\hline $\mathrm{ZnO}$ & & & & & & 0.32 & 0.18 \\
\hline $\mathrm{CaO}$ & 0.04 & 0.43 & 0.51 & 22.47 & 22.18 & & \\
\hline $\mathrm{Na}_{2} \mathrm{O}$ & 0.01 & 0.06 & 0.02 & 1.22 & 1.02 & & \\
\hline $\mathrm{K}_{2} \mathrm{O}$ & bd. & 0.12 & bd. & bd. & 0.02 & & \\
\hline Total & 100.11 & 100.63 & 100.42 & 98.96 & 99.49 & 100.35 & 100.29 \\
\hline Fo & 92 & & & & & & \\
\hline $\mathrm{FeOl}$ & & & & & & 16.08 & 15.76 \\
\hline $\mathrm{Mg} \#$ & & 91.7 & 91.7 & 94.7 & 95.7 & & \\
\hline $\mathrm{Cr} \#$ & & & & & & 31.8 & 33.8 \\
\hline
\end{tabular}

"calculated using the procedure of [56];

$\mathrm{Mg} \#=100 *(\mathrm{Mg}) /(\mathrm{Mg}+\mathrm{Fe}) ; \mathrm{Cr} \#=100 *(\mathrm{Cr}) /(\mathrm{Cr}+\mathrm{Al})$

bd. $=$ below detection limit

A portion of sample \#3 consists of a symplectite formed by an intergrowth of calcite, chromite and ilmenite, the latter with abundant thin exsolution lamellae (Figure 8(c)).

\subsection{Mineral compositions}

Representative compositions of the main minerals of sample \#3 are presented in Table 5 . Clinopyroxene is $\mathrm{Al}$ and $\mathrm{Ti}$-poor (0.04-0.6 wt.\% $\mathrm{Al}_{2} \mathrm{O}_{3} ; 0.07-0.8$ wt.\% $\mathrm{TiO}_{2}$ )

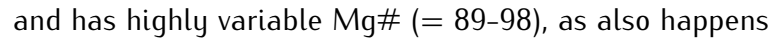
to olivine $\left(\mathrm{Fo}_{81-90}\right)$. No representative in situ traceelement analyses of clinopyroxene could be obtained by LA-ICPMS in view of the abundance of inclusions.

Phlogopite is $\mathrm{Al}$-poor (9.9-10.4 wt.\% $\mathrm{Al}_{2} \mathrm{O}_{3}$ ), resulting in tetrahedral site deficiency $(\mathrm{Si}+\mathrm{Al}=7.67-7.88$, Table 5). It is strongly zoned from darker rims with high $\mathrm{TiO}_{2}$ and $\mathrm{FeO}_{\mathrm{T}}$ (up to $4 \mathrm{wt} . \%$ and $10 \mathrm{wt} . \%$, respectively) and light cores with up to 1 wt.\% $\mathrm{TiO}_{2}$ and 7.5 wt.\% $\mathrm{FeO}_{\mathrm{T}}$. The compositions plot in fields of MARID and kimberlite micas and of the micas from the Leucite Hills lamproite (Figure 4(a)).

Ilmenite is Mg-rich (8.6-9.8 wt.\% MgO), but lower in $\mathrm{Mg}$ and much lower in $\mathrm{Cr}$ compared with ilmenite from sample \#2 (Figure 4(b)). Ilmenite hosting priderite lamellae and ilmenite rimming priderite are chemically very similar, but the former has lower $\mathrm{Cr}$ and $\mathrm{Mg}$ (Table 5). In contrast to ilmenite from sample \#2, these compositions are closer to the $\mathrm{Mg}$-poor arm of the mantle ilmenite parabola (Figure 4(b)).

Representative compositions of priderite from sample \#3 are shown in Table 6. Chemical formulae show important deviations from the ideal $\mathrm{A}_{(}\left(\mathrm{Ti}_{7}^{4+} \mathrm{M}^{3+}\right) \mathrm{O}_{16}$ with the A-site well in excess of 1 cation per formula unit (1.4-1.9) and $M$ usually slightly below 8 (7.657.95). The compositions of the priderite lamellae within the large ilmenite crystals are relatively homogeneous and show some subtle systematic differences from the compositionally more variable priderite that occurs as patches in rutile, even taking into account that a small part of the variability of the latter may reflect the incorporation of microdomains of rutile (darker areas in Figure 8(f)) that could not be avoided with a $\sim 2 \mu \mathrm{m}$ electron beam.

Very low Ba contents are typical of both varieties of priderite: atomic $\mathrm{Ba} /(\mathrm{Ba}+\mathrm{K})$ is slightly lower in the lamellae in ilmenite $(0.014-0.021)$ as compared to the patches in rutile $(0.024-0.047)$. These compositions are much Ba-poorer than most reported occurrences of priderite from lamproites [39], carbonatites [38] and xenoliths derived from the high-pressure crystallization of a lamproitic magma [11], for which typical $\mathrm{Ba} /(\mathrm{Ba}+\mathrm{K})$ is 

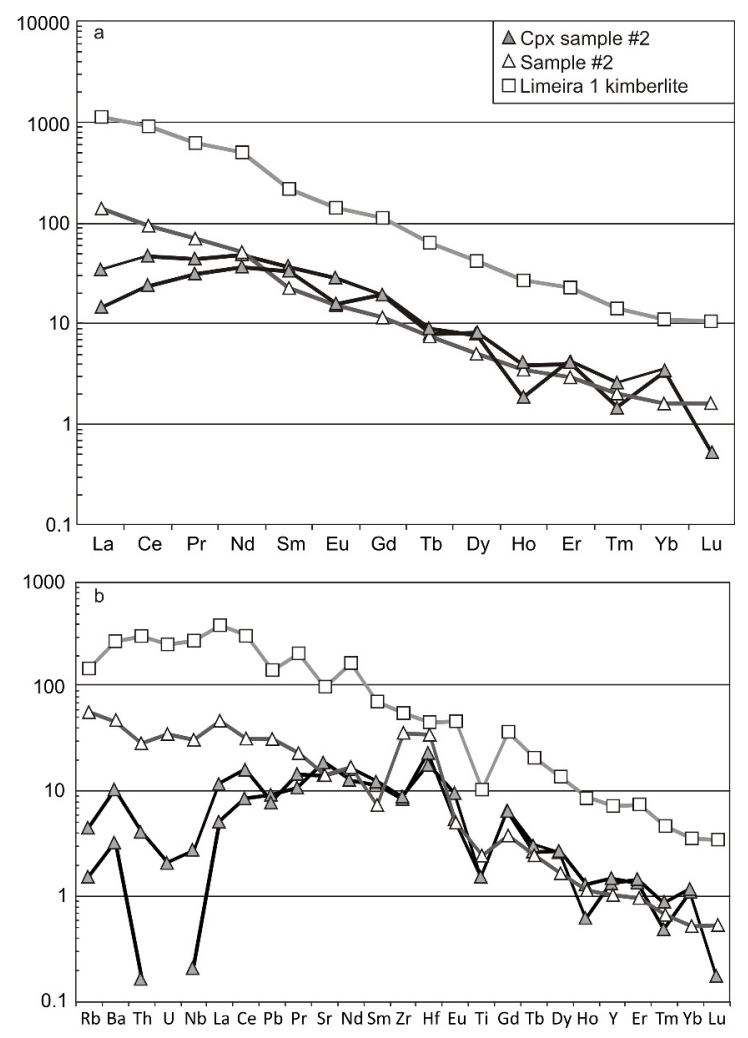

Figure 5. (a) Chondrite-normalized REE patterns of clinopyroxene (Cpx) from sample \#2 in comparison with whole rock composition of sample \#2 and Limeira 1 kimberlite. Normalizing factors from [53]; (b) Primitive mantle normalized trace element patterns for clinopyroxene from the sample \#2 with whole rock composition of sample \#2 and Limeira 1 kimberlite. Normalizing factors from [54].

$\sim 0.2-0.4$. Nearly Ba-free priderites are found as anhedral crystals interpreted to be xenocrysts in the Star mine orangeite, South Africa, where they differ from groundmass (magmatic) Ba-rich priderites [40].

$\mathrm{Nb}$ and $\mathrm{Cr}$ are more abundant in the lamellae priderite, where they show a positive correlation (Figure 9(a),(b)); considered together with the data from patchy priderite, a roughly $1: 1$ correlation is observed, indicating that these cations can replace part of the $\mathrm{Ti}^{4+}$ through a chargebalanced exchange: $2 \mathrm{Ti}^{4+}=\mathrm{Nb}^{5+}+\mathrm{Cr}^{3+}$. This exchange may account for most (60-100\%) of the deviation of total Ti from the ideal 7 cations. $\mathrm{Zr}^{4+}$ is more abundant in the rutile-derived patchy priderite which therefore has consistently higher $\mathrm{Zr} / \mathrm{Nb}$ as compared to the ilmeniteassociated priderite lamellae (0.18-0.25 versus $0.03-0.05)$. A-site excess relative to the ideal formula is typical of nearly all natural priderites. The "ideal" 1 A cation per formula unit corresponds to $50 \%$ occupancy of the large
Table 3. Trace-element composition of clinopyroxene from sample \#2 by LA-ICPMS compared to whole-rock and host kimberlite.

\begin{tabular}{|c|c|c|c|c|}
\hline & Cpx & Cpx & sample \#2 & $\begin{array}{c}\text { Limeira } 1 \\
\text { kimberlite }\end{array}$ \\
\hline $\mathrm{Rb}$ & 2.86 & 0.96 & 36.8 & 95.5 \\
\hline $\mathrm{Sr}$ & 302.88 & 395.42 & 307 & 2105 \\
\hline Y & 6.87 & 6.05 & 4.76 & 33.5 \\
\hline $\mathrm{Zr}$ & 100.15 & 93.71 & 407 & 633 \\
\hline $\mathrm{Nb}$ & 1.96 & 0.14 & 22.5 & 197 \\
\hline $\mathrm{Ba}$ & 72.36 & 22.56 & 327 & 1911 \\
\hline La & 8.09 & 3.48 & 32.9 & 267 \\
\hline $\mathrm{Ce}$ & 28.58 & 14.99 & 57.5 & 559 \\
\hline $\operatorname{Pr}$ & 4.05 & 2.95 & 6.49 & 57.7 \\
\hline $\mathrm{Nd}$ & 22.19 & 17.09 & 23.5 & 229 \\
\hline Sm & 5.47 & 4.99 & 3.34 & 32.2 \\
\hline $\mathrm{Eu}$ & 1.59 & 0.90 & 0.86 & 7.95 \\
\hline Gd & 3.82 & 3.92 & 2.3 & 22.3 \\
\hline $\mathrm{Tb}$ & 0.29 & 0.33 & 0.27 & 2.29 \\
\hline Dy & 2.00 & 1.91 & 1.24 & 10.3 \\
\hline Ho & 0.21 & 0.10 & 0.19 & 1.47 \\
\hline $\mathrm{Er}$ & 0.65 & 0.69 & 0.47 & 3.65 \\
\hline Tm & 0.04 & 0.06 & 0.05 & 0.35 \\
\hline $\mathrm{Yb}$ & 0.54 & 0.57 & 0.26 & 1.78 \\
\hline $\mathrm{Lu}$ & 0.01 & bd. & 0.04 & 0.26 \\
\hline $\mathrm{Hf}$ & 5.54 & 7.10 & 10.9 & 14.3 \\
\hline Ta & 0.16 & 0.01 & 1.91 & 12.7 \\
\hline $\mathrm{Pb}$ & 0.56 & 0.65 & 2.28 & 10.3 \\
\hline Th & 0.35 & 0.01 & 2.48 & 26 \\
\hline U & 0.04 & bd. & 0.75 & 5.37 \\
\hline
\end{tabular}

tunnel sites of the hollandite structure, but [36] consider that maximum occupancy of $\mathrm{Ba}^{2+}$ may reach 1.33 atoms pfu. Excess charge may be compensated in several ways, one of the most obvious being the exchange of trivalent by divalent cations in $\mathrm{M}$. A minimum of $0.1-0.25 \mathrm{R}^{2+}$ atoms pfu. is present in all Limeira 1 priderites as $\mathrm{Mg}^{2+}$, which compensates for up to $50 \%$ excess charge associated with monovalent cations $\left(\mathrm{K}^{+}\right.$and $\left.\mathrm{Na}^{+}\right)$in the $A$ site in some analyses; this may be increased if part of the $\mathrm{Fe}$ is divalent.

Analyses \#7-9 (Table 6), however, differ from the remaining ones as the contents of $\mathrm{K}_{2} \mathrm{O}$ (10.2-12.1 wt.\%) and $\mathrm{TiO}_{2}$ (76.3-79.9 wt.\%) are remarkably higher, and formulae calculated for 16 oxygens result in total $A$ close to 2 , and total $M$ much lower than 8 (7.6-7.8). This raises a question whether they in fact correspond to priderite, or represent another titanate with different structure, such 
Table 4. Representative electron microprobe analyses of mathiasite-loveringite from sample \#2. bd. = below detection limit.

\begin{tabular}{|c|c|c|c|c|c|c|c|c|c|c|c|c|c|}
\hline analysis \# & 1 & 2 & 3 & 4 & 5 & 6 & 7 & 8 & 9 & 10 & 11 & 12 & average \\
\hline $\mathrm{Nb}_{2} \mathrm{O}_{5}$ & 0.21 & 0.21 & 0.20 & 0.19 & 0.14 & 0.24 & 0.18 & 0.17 & 0.16 & 0.17 & 0.21 & 0.15 & 0.18 \\
\hline $\mathrm{SiO}_{2}$ & 0.00 & 0.04 & 0.05 & 0.06 & 0.05 & 0.07 & 0.01 & 0.10 & 0.00 & 0.04 & 0.05 & 0.00 & 0.04 \\
\hline $\mathrm{TiO}_{2}$ & 60.24 & 60.40 & 58.56 & 59.77 & 59.09 & 59.00 & 60.10 & 58.81 & 59.52 & 59.47 & 59.61 & 58.84 & 59.50 \\
\hline $\mathrm{ZrO}_{2}$ & 5.83 & 5.80 & 5.83 & 5.66 & 5.82 & 5.90 & 6.12 & 6.02 & 6.09 & 6.02 & 5.84 & 5.77 & 5.84 \\
\hline $\mathrm{Al}_{2} \mathrm{O}_{3}$ & 0.82 & 0.77 & 0.78 & 0.76 & 0.77 & 0.84 & 0.76 & 0.82 & 0.79 & 0.81 & 0.78 & 0.82 & 0.78 \\
\hline $\mathrm{Cr}_{2} \mathrm{O}_{3}$ & 14.35 & 14.62 & 14.62 & 15.18 & 14.61 & 14.50 & 13.78 & 13.85 & 13.98 & 14.82 & 14.32 & 14.11 & 14.43 \\
\hline $\mathrm{La}_{2} \mathrm{O}_{3}$ & 0.34 & 0.21 & 0.18 & 0.14 & 0.27 & 0.32 & 0.18 & 0.31 & 0.24 & 0.16 & 0.20 & 0.28 & 0.22 \\
\hline $\mathrm{Ce}_{2} \mathrm{O}_{3}$ & 0.27 & 0.32 & 0.32 & 0.23 & 0.34 & 0.32 & 0.35 & 0.28 & 0.23 & 0.33 & 0.23 & 0.32 & 0.32 \\
\hline $\mathrm{MgO}$ & 3.29 & 3.18 & 3.22 & 3.22 & 3.24 & 3.15 & 3.36 & 3.21 & 3.40 & 3.25 & 3.12 & 3.26 & 3.23 \\
\hline $\mathrm{ZnO}$ & 0.04 & 0.01 & bd. & 0.01 & bd. & bd. & 0.03 & bd. & bd. & 0.04 & bd. & bd. & bd. \\
\hline $\mathrm{MnO}$ & 0.11 & 0.07 & 0.09 & 0.07 & 0.05 & 0.08 & 0.04 & 0.03 & 0.08 & 0.09 & 0.10 & 0.10 & 0.08 \\
\hline $\mathrm{FeO}$ & 10.24 & 10.91 & 10.15 & 10.66 & 10.73 & 11.07 & 11.22 & 10.89 & 11.05 & 10.74 & 10.51 & 10.54 & 10.73 \\
\hline $\mathrm{CaO}$ & 1.47 & 1.51 & 1.57 & 1.49 & 1.58 & 1.45 & 1.54 & 1.48 & 1.49 & 1.42 & 1.46 & 1.49 & 1.49 \\
\hline $\mathrm{SrO}$ & 0.62 & 0.61 & 0.54 & 0.71 & 0.68 & 0.70 & 0.41 & 0.78 & 0.57 & 0.64 & 0.71 & 0.60 & 0.63 \\
\hline $\mathrm{BaO}$ & 0.54 & 0.43 & 0.65 & 0.42 & 0.43 & 0.41 & 0.47 & 0.56 & 0.49 & 0.62 & 0.65 & 0.51 & 0.50 \\
\hline $\mathrm{Na}_{2} \mathrm{O}$ & 0.06 & 0.04 & 0.08 & 0.03 & 0.13 & 0.07 & 0.05 & 0.12 & 0.13 & 0.08 & 0.09 & 0.10 & 0.08 \\
\hline $\mathrm{K}_{2} \mathrm{O}$ & 0.84 & 0.86 & 0.91 & 0.90 & 0.97 & 0.85 & 1.02 & 0.87 & 1.02 & 0.82 & 1.05 & 0.79 & 0.89 \\
\hline Total & 99.27 & 99.98 & 97.74 & 99.49 & 98.90 & 98.97 & 99.62 & 98.31 & 99.22 & 99.53 & 98.91 & 97.68 & 99.10 \\
\hline $\mathrm{Nb}$ & 027 & 0.027 & 0.026 & 0.025 & 0.019 & 0.032 & 0.023 & 0.023 & 0.021 & 0.022 & 0.028 & 0.0 & 0.024 \\
\hline $\mathrm{Si}$ & 0.000 & 0.012 & 0.016 & 0.016 & 0.015 & 0.019 & 0.004 & 0.028 & 0.000 & 0.012 & 0.013 & 0.000 & 0.013 \\
\hline $\mathrm{Ti}$ & 13.077 & 13.032 & 12.939 & 12.955 & 12.924 & 12.903 & 13.033 & 12.953 & 12.973 & 12.921 & 13.026 & 13.004 & 12.964 \\
\hline $\mathrm{Zr}$ & 0.820 & 0.811 & 0.835 & 0.796 & 0.824 & 0.836 & 0.861 & 0.859 & 0.861 & 0.848 & 0.827 & 0.827 & 0.831 \\
\hline $\mathrm{Al}$ & 0.278 & 0.260 & 0.270 & 0.259 & 0.264 & 0.287 & 0.259 & 0.282 & 0.268 & 0.275 & 0.266 & 0.284 & 0.269 \\
\hline $\mathrm{Cr}$ & 3.274 & 3.316 & 3.396 & 3.459 & 3.357 & 3.333 & 3.141 & 3.206 & 3.202 & 3.385 & 3.288 & 3.278 & 3.302 \\
\hline La & 0.036 & 0.022 & 0.019 & 0.015 & 0.029 & 0.035 & 0.019 & 0.034 & 0.025 & 0.017 & 0.021 & 0.031 & 0.024 \\
\hline $\mathrm{Ce}$ & 0.029 & 0.034 & 0.034 & 0.024 & 0.036 & 0.034 & 0.037 & 0.030 & 0.024 & 0.035 & 0.024 & 0.034 & 0.034 \\
\hline $\mathrm{Mg}$ & 1.416 & 1.359 & 1.411 & 1.384 & 1.404 & 1.366 & 1.443 & 1.401 & 1.468 & 1.398 & 1.353 & 1.427 & 1.403 \\
\hline $\mathrm{Zn}$ & 0.008 & 0.001 & 0.000 & 0.001 & 0.000 & 0.000 & 0.006 & & 0.000 & 0.009 & 0.000 & 0.000 & 0.000 \\
\hline $\mathrm{Mn}$ & 0.026 & 0.016 & 0.021 & 0.018 & 0.012 & 0.020 & 0.010 & 0.008 & 0.018 & 0.022 & 0.023 & 0.026 & 0.019 \\
\hline $\mathrm{Fe}$ & 2.472 & 2.618 & 2.492 & 2.569 & 2.609 & 2.690 & 2.705 & 2.667 & 2.677 & 2.593 & 2.553 & 2.589 & 2.601 \\
\hline $\mathrm{Ca}$ & 0.455 & 0.464 & 0.495 & 0.460 & 0.492 & 0.450 & 0.477 & 0.465 & 0.462 & 0.439 & 0.454 & 0.468 & 0.463 \\
\hline $\mathrm{Sr}$ & 0.104 & 0.101 & 0.091 & 0.118 & 0.114 & 0.117 & 0.068 & 0.132 & 0.096 & 0.107 & 0.120 & 0.101 & 0.105 \\
\hline $\mathrm{Ba}$ & 0.061 & 0.048 & 0.075 & 0.047 & 0.049 & 0.046 & 0.053 & 0.064 & 0.056 & 0.071 & 0.074 & 0.059 & 0.057 \\
\hline $\mathrm{Na}$ & 0.031 & 0.023 & 0.045 & 0.015 & 0.073 & 0.041 & 0.030 & 0.069 & 0.071 & 0.047 & 0.050 & 0.056 & 0.046 \\
\hline K & 0.311 & 0.313 & 0.342 & 0.332 & 0.360 & 0.317 & 0.375 & 0.326 & 0.377 & 0.303 & 0.390 & 0.298 & 0.329 \\
\hline Total M & 21.399 & 21.451 & 21.404 & 21.481 & 21.428 & 21.488 & 21.485 & 21.427 & 21.488 & 21.485 & 21.378 & 21.455 & 21.453 \\
\hline Total A & 1.026 & 1.006 & 1.102 & 1.011 & 1.153 & 1.040 & 1.058 & 1.120 & 1.110 & 1.019 & 1.134 & 1.047 & 1.052 \\
\hline $\mathrm{Al}+\mathrm{Zn}+\mathrm{Si}(\mathrm{T})$ & 0.286 & 0.273 & 0.285 & 0.276 & 0.279 & 0.307 & 0.269 & 0.310 & 0.268 & 0.295 & 0.279 & 0.284 & 0.281 \\
\hline $\mathrm{Zr}+\mathrm{Mn}(\mathrm{B})$ & 0.846 & 0.827 & 0.856 & 0.814 & 0.836 & 0.856 & 0.871 & 0.867 & 0.879 & 0.870 & 0.851 & 0.853 & 0.855 \\
\hline Total C & 17.795 & 17.734 & 17.771 & 17.822 & 17.704 & 17.634 & 17.640 & 17.583 & 17.664 & 17.727 & 17.695 & 17.729 & 17.715 \\
\hline $\mathrm{Ti} / \mathrm{Nb}$ & 487 & 486 & 500 & 526 & 683 & 402 & 565 & 562 & 608 & 579 & 468 & 644 & 544 \\
\hline $\mathrm{Ti} / \mathrm{Zr}$ & 16.0 & 16.1 & 15.5 & 16.3 & 15.7 & 15.4 & 15.1 & 15.1 & 15.1 & 15.2 & 15.7 & 15.7 & 15.6 \\
\hline
\end{tabular}


Table 5. Representative electron microprobe analyses of minerals from sample \#3.

\begin{tabular}{|c|c|c|c|c|c|c|c|c|c|c|c|c|c|c|c|}
\hline Mineral & $\mathrm{Ol}$ & $\mathrm{Ol}$ & Cpx & Cpx & Cpx & Cpx & Mineral & $\mathrm{Ilm}$ & Ilm & Mineral & $\mathrm{Phl}$ & $\mathrm{Phl}$ & $\mathrm{Phl}$ & $\mathrm{Phl}$ & Phl \\
\hline $\mathrm{SiO}_{2}$ & 39.40 & 38.37 & 54.07 & 53.80 & 53.69 & 53.40 & $\mathrm{Nb}_{2} \mathrm{O}_{5}$ & 0.14 & 0.06 & $\mathrm{SiO}_{2}$ & 41.14 & 41.39 & 38.79 & 39.62 & 41.43 \\
\hline $\mathrm{TiO}_{2}$ & 0.04 & 0.06 & 0.14 & 0.54 & 0.78 & 0.84 & $\mathrm{SiO}_{2}$ & 0.04 & 0.02 & $\mathrm{TiO}_{2}$ & 0.96 & 1.09 & 3.95 & 3.25 & 1.03 \\
\hline $\mathrm{Al}_{2} \mathrm{O}_{3}$ & 0.02 & 0.37 & 0.52 & 0.24 & 0.04 & 0.20 & $\mathrm{TiO}_{2}$ & 50.71 & 49.30 & $\mathrm{Al}_{2} \mathrm{O}_{3}$ & 10.11 & 10.38 & 10.35 & 10.19 & 10.31 \\
\hline $\mathrm{Cr}_{2} \mathrm{O}_{3}$ & 0.07 & 0.06 & 0.30 & 0.34 & 0.12 & 0.48 & $\mathrm{ZrO}_{2}$ & 0.05 & 0.03 & $\mathrm{FeO}$ & 7.50 & 7.39 & 9.92 & 9.80 & 7.74 \\
\hline $\mathrm{FeO}$ & 9.51 & 17.97 & 6.17 & 4.80 & 2.70 & 3.77 & $\mathrm{Al}_{2} \mathrm{O}_{3}$ & 0.06 & 0.05 & $\mathrm{MnO}$ & 0.05 & 0.03 & 0.03 & 0.05 & 0.06 \\
\hline $\mathrm{MnO}$ & 0.24 & 0.35 & 0.09 & 0.13 & 0.02 & 0.09 & $\mathrm{Cr}_{2} \mathrm{O}_{3}$ & 1.78 & 0.46 & $\mathrm{MgO}$ & 22.37 & 22.60 & 19.72 & 20.58 & 22.65 \\
\hline $\mathrm{NiO}$ & 0.09 & 0.10 & & & & & $\mathrm{MgO}$ & 9.78 & 8.61 & $\mathrm{CaO}$ & 0.03 & 0.06 & 0.03 & 0.06 & 0.00 \\
\hline $\mathrm{MgO}$ & 48.68 & 42.85 & 15.02 & 16.16 & 16.55 & 16.47 & $\mathrm{ZnO}$ & 0.06 & 0.04 & $\mathrm{BaO}$ & 0.21 & 0.21 & 0.24 & 0.16 & 0.25 \\
\hline $\mathrm{CaO}$ & 1.11 & 0.13 & 21.40 & 22.20 & 24.71 & 23.39 & $\mathrm{MnO}$ & 0.52 & 0.55 & $\mathrm{Na}_{2} \mathrm{O}$ & 0.23 & 0.37 & 0.05 & 0.03 & 0.44 \\
\hline $\mathrm{Na}_{2} \mathrm{O}$ & 0.02 & 0.04 & 1.55 & 0.88 & 0.63 & 0.55 & $\mathrm{FeO}$ & 36.92 & 37.82 & $\mathrm{~K}_{2} \mathrm{O}$ & 10.44 & 10.24 & 10.12 & 10.16 & 10.44 \\
\hline $\mathrm{K}_{2} \mathrm{O}$ & 0.00 & 0.00 & 0.01 & 0.20 & 0.09 & 0.01 & $\mathrm{CaO}$ & 0.05 & 0.02 & Total & 93.04 & 93.76 & 93.20 & 93.90 & 94.35 \\
\hline Total & 99.2 & 100.3 & 99.3 & 99.3 & 99.3 & 99.2 & $\mathrm{SrO}$ & 0.06 & 0.06 & $\mathrm{~F}$ & 0.38 & 0.36 & 0.39 & 0.57 & 0.78 \\
\hline Fo & 90 & 81 & & & & & Total & 100.31 & 97.24 & $\mathrm{Cl}$ & 0.04 & 0.03 & 0.01 & 0.01 & 0.03 \\
\hline \multirow[t]{5}{*}{$\mathrm{Mg} \#$} & & & 89.1 & 91.3 & 98.4 & 91.9 & & & & $\mathrm{Si}$ & 6.11 & 6.08 & 5.84 & 5.90 & 6.07 \\
\hline & & & & & & & & & & Al IV & 1.77 & 1.80 & 1.84 & 1.79 & 1.78 \\
\hline & & & & & & & & & & $\mathrm{Al} \mathrm{VI}$ & 0.00 & 0.00 & 0.00 & 0.00 & 0.00 \\
\hline & & & & & & & & & & Total IV & 7.87 & 7.88 & 7.67 & 7.69 & 7.85 \\
\hline & & & & & & & & & & $\mathrm{Mg \#}$ & 84 & 85 & 78 & 79 & 84 \\
\hline
\end{tabular}

$\mathrm{Mg} \#=100 *(\mathrm{Mg}) /(\mathrm{Mg}+\mathrm{Fe}) ; \mathrm{Cr} \#=100^{*}(\mathrm{Cr}) /(\mathrm{Cr}+\mathrm{Al})$; cationic proportions in phlogopite calculated on the basis of $22 \mathrm{O}$

as K-triskaidecatitanate (with ideal formula $\mathrm{K}_{2} \mathrm{Ti}_{13} \mathrm{O}_{27}$ ). Calculated on the basis of 27 oxygens, these analyses would correspond to a formula $\mathrm{K}_{2.1} \mathrm{Ti}_{12}\left(\mathrm{Fe}^{3+}, \mathrm{Cr}^{3+}\right) \mathrm{O}_{27}$, comparable to K-triskaidecatitanates from African orangeites $\left(\mathrm{K}_{2.19} \mathrm{Ti}_{13.28} \mathrm{O}_{27} ;[41]\right)$ and an ultrapotassic rock from the Damodar Valley, India $\left(\mathrm{K}_{2.15} \mathrm{Ti}_{12.24} \mathrm{O}_{27}\right.$; [42]).

\section{Discussion}

\subsection{Formation of mathiasite}

Mathiasite occurs strictly as part of double reaction rim coronas developed around chromite and subordinately ilmenite from peridotite xenoliths of the Limeira 1 intrusion. The disequilibrium textures observed in sample \#2 indicate that clinopyroxene and phlogopite were formed at the expense of primary olivine and orthopyroxene through a reaction with melt, as evidenced by the presence of melt inclusions [43]. Clinopyroxene is $\mathrm{Al}_{2} \mathrm{O}_{3}$-poor whereas phlogopite has a slight deficit in tetrahedral $\mathrm{Al}(\mathrm{Si}+\mathrm{AlT}<8)$ indicative of the presence of tetrahedral $\mathrm{Fe}^{3+}$ [44]. Chromite is Ti-rich, which is considered an indication of compositional modification by kimberlite-like metasomatism [33, 45]. Convex-upward LREE patterns such as those shown by the clinopyroxene $\left.\left((\mathrm{La} / \mathrm{Nd})_{\mathrm{N}}<1\right)\right)$ are interpreted by some other studies as resulting from interaction between highly alkaline melts and depleted peridotite [46].

The double reaction rim coronas formed by reaction of the primary minerals from a previously depleted peridotite with an incompatible-element enriched melt (Figure 10(a)). The clinopyroxene-phlogopite corona and ilmenite should have formed first (Figure 10(b)), and mathiasite-loveringite was produced in the progression of the metasomatism as a result of the reaction between the clinopyroxene-phlogopite corona with chromite (Figure 10(c)); this is in agreement with the observations of [33] that the spinel involved in the formation of crichtonite minerals is typically refractory with high contents of $\mathrm{Cr}_{2} \mathrm{O}_{3}$.

The preservation of disequilibrium textures suggests that the reactions that led to the formation of the double reaction rim coronas occurred shortly prior to the entrainment of the xenolith in the host magma. Reaction products related to infiltration of fluids/melts from the Ca-rich host magma occur as thin perovskite-magnetite(barite) films that replace the oxides along their borders and cracks.

\subsection{Formation of priderite}

Priderite occurs as lamellae within ilmenite and is intergrown with rutile that may be included in sagenitic 
Table 6. Representative electron microprobe analyses of priderite from sample \#3.

\begin{tabular}{|c|c|c|c|c|c|c|c|c|c|c|c|}
\hline Analysis \# & 1 & 2 & 3 & 4 & 5 & 6 & 7 & 8 & 9 & 10 & 11 \\
\hline $\mathrm{Nb}_{2} \mathrm{O}_{5}$ & 3.39 & 3.4 & 2.97 & 3.58 & 3.97 & 1.67 & 1.84 & 2.41 & 1.56 & 1.94 & 3.42 \\
\hline $\mathrm{SiO}_{2}$ & 0.1 & 0.05 & bd. & bd. & 0.05 & bd. & bd. & bd. & 0.04 & bd. & bd. \\
\hline $\mathrm{TiO}_{2}$ & 70.32 & 70.89 & 75.68 & 71.15 & 69.28 & 74.61 & 76.43 & 76.28 & 79.94 & 75.85 & 71.14 \\
\hline $\mathrm{ZrO}_{2}$ & 0.1 & 0.1 & 0.13 & 0.11 & 0.15 & 0.32 & 0.31 & 0.49 & 0.36 & 0.35 & 0.13 \\
\hline $\mathrm{Al}_{2} \mathrm{O}_{3}$ & 0.04 & 0.07 & 0.04 & 0.04 & 0.08 & 0.16 & bd. & bd. & 0.04 & 0.06 & 0.01 \\
\hline $\mathrm{Fe}_{2} \mathrm{O}_{3}$ & 10.38 & 10.84 & 8.24 & 9.62 & 11.20 & 8.80 & 4.61 & 5.04 & 3.47 & 8.30 & 11.22 \\
\hline $\mathrm{Cr}_{2} \mathrm{O}_{3}$ & 2.36 & 2.21 & 1.87 & 2.06 & 2.58 & 1.69 & 1.19 & 1.02 & 1.49 & 1.77 & 2.52 \\
\hline $\mathrm{La}_{2} \mathrm{O}_{3}$ & bd. & bd. & bd. & bd. & 0.04 & 0.02 & bd. & bd. & 0.08 & 0.02 & bd. \\
\hline $\mathrm{Ce}_{2} \mathrm{O}_{3}$ & 0.06 & 0.08 & 0.07 & 0.05 & bd. & 0.09 & 0.12 & 0.08 & 0.03 & 0.06 & 0.07 \\
\hline $\mathrm{MgO}$ & 0.75 & 0.72 & 1.21 & 1.2 & 0.97 & 1.44 & 0.64 & 1.08 & 0.52 & 1.3 & 2.05 \\
\hline $\mathrm{ZnO}$ & bd. & bd. & bd. & 0.02 & bd. & 0.04 & bd. & 0.03 & 0.04 & 0.04 & bd. \\
\hline $\mathrm{MnO}$ & bd. & bd. & 0.01 & 0.02 & bd. & bd. & bd. & bd. & bd. & bd. & 0.06 \\
\hline $\mathrm{CaO}$ & 0.82 & 0.48 & 0.03 & 0.17 & 0.58 & 0.73 & 0.01 & 0.06 & 0.02 & 0.14 & 0.04 \\
\hline $\mathrm{SrO}$ & 0.04 & 0.06 & bd. & bd. & 0.12 & 0.11 & 0.08 & 0.03 & 0.03 & 0.01 & 0.09 \\
\hline $\mathrm{BaO}$ & 0.43 & 0.6 & 0.39 & 0.37 & 0.61 & 1.31 & 1.18 & 0.87 & 0.96 & 1.13 & 0.33 \\
\hline $\mathrm{Na}_{2} \mathrm{O}$ & 0.57 & 0.46 & 0.31 & 0.49 & 0.57 & 0.06 & 0.23 & 0.12 & 0.22 & 0.08 & 0.37 \\
\hline $\mathrm{K}_{2} \mathrm{O}$ & 8.67 & 8.57 & 8.72 & 8.62 & 8.9 & 8.2 & 11.84 & 10.21 & 12.08 & 8.64 & 8.08 \\
\hline Total & 98.03 & 98.53 & 99.67 & 97.50 & 99.10 & 99.25 & 98.48 & 97.72 & 100.88 & 99.69 & 99.53 \\
\hline $\mathrm{Nb}$ & 0.185 & 0.184 & 0.157 & 0.195 & 0.215 & 0.089 & 0.100 & 0.131 & 0.082 & 0.103 & 0.183 \\
\hline $\mathrm{Si}$ & 0.012 & 0.006 & 0.000 & 0.000 & 0.006 & 0.000 & 0.000 & 0.000 & 0.005 & 0.000 & 0.000 \\
\hline $\mathrm{Ti}$ & 6.372 & 6.391 & 6.656 & 6.452 & 6.249 & 6.624 & 6.901 & 6.872 & 7.002 & 6.692 & 6.315 \\
\hline $\mathrm{Zr}$ & 0.006 & 0.006 & 0.007 & 0.006 & 0.009 & 0.018 & 0.018 & 0.029 & 0.020 & 0.020 & 0.007 \\
\hline Al & 0.006 & 0.010 & 0.006 & 0.006 & 0.011 & 0.022 & 0.000 & 0.000 & 0.005 & 0.008 & 0.001 \\
\hline $\mathrm{Cr}$ & 0.225 & 0.209 & 0.173 & 0.196 & 0.245 & 0.158 & 0.113 & 0.097 & 0.137 & 0.164 & 0.235 \\
\hline $\mathrm{Fe}^{3+}$ & 0.941 & 0.978 & 0.726 & 0.873 & 1.011 & 0.782 & 0.417 & 0.455 & 0.304 & 0.733 & 0.997 \\
\hline La & & & & & 0.002 & 0.001 & & & 0.003 & 0.001 & \\
\hline $\mathrm{Ce}$ & 0.003 & 0.004 & 0.003 & 0.002 & 0.000 & 0.004 & 0.005 & 0.004 & 0.001 & 0.003 & 0.003 \\
\hline $\mathrm{Mg}$ & 0.135 & 0.129 & 0.211 & 0.216 & 0.173 & 0.253 & 0.115 & 0.193 & 0.090 & 0.227 & 0.361 \\
\hline $\mathrm{Zn}$ & & & & 0.002 & & 0.003 & 0.000 & 0.003 & 0.003 & 0.003 & \\
\hline $\mathrm{Mn}$ & & & 0.001 & 0.002 & & 0.000 & & & & & 0.006 \\
\hline $\mathrm{Ca}$ & 0.106 & 0.062 & 0.004 & 0.022 & 0.075 & 0.092 & 0.001 & 0.008 & 0.002 & 0.018 & 0.005 \\
\hline $\mathrm{Sr}$ & 0.003 & 0.004 & & & 0.008 & 0.008 & 0.006 & 0.002 & 0.002 & 0.001 & 0.006 \\
\hline $\mathrm{Ba}$ & 0.020 & 0.028 & 0.018 & 0.017 & 0.029 & 0.061 & 0.056 & 0.041 & 0.044 & 0.052 & 0.015 \\
\hline $\mathrm{Na}$ & 0.133 & 0.107 & 0.070 & 0.115 & 0.133 & 0.014 & 0.054 & 0.028 & 0.050 & 0.018 & 0.085 \\
\hline K & 1.333 & 1.311 & 1.301 & 1.326 & 1.362 & 1.235 & 1.814 & 1.560 & 1.795 & 1.293 & 1.217 \\
\hline Total & 9.479 & 9.429 & 9.333 & 9.430 & 9.527 & 9.365 & 9.597 & 9.420 & 9.547 & 9.335 & 9.436 \\
\hline Total M & 7.881 & 7.914 & 7.937 & 7.948 & 7.919 & 7.951 & 7.663 & 7.778 & 7.649 & 7.950 & 8.105 \\
\hline Total A & 1.598 & 1.515 & 1.396 & 1.482 & 1.608 & 1.414 & 1.935 & 1.642 & 1.898 & 1.385 & 1.331 \\
\hline $\mathrm{Ba} /(\mathrm{K}+\mathrm{Ba})$ & 0.015 & 0.021 & 0.014 & 0.013 & 0.021 & 0.047 & 0.030 & 0.026 & 0.024 & 0.039 & 0.012 \\
\hline $\mathrm{Nb} / \mathrm{Zr}$ & 31.4 & 31.5 & 21.2 & 30.2 & 24.5 & 4.8 & 5.5 & 4.6 & 4.0 & 5.1 & 24.4 \\
\hline $\mathrm{Ti} / \mathrm{Zr}$ & 1084 & 1093 & 898 & 998 & 712 & 360 & 380 & 240 & 342 & 334 & 844 \\
\hline $\mathrm{Ti} / \mathrm{Nb}$ & 35 & 35 & 42 & 33 & 29 & 74 & 69 & 53 & 85 & 65 & 35 \\
\hline
\end{tabular}

bd. = below detection limit 


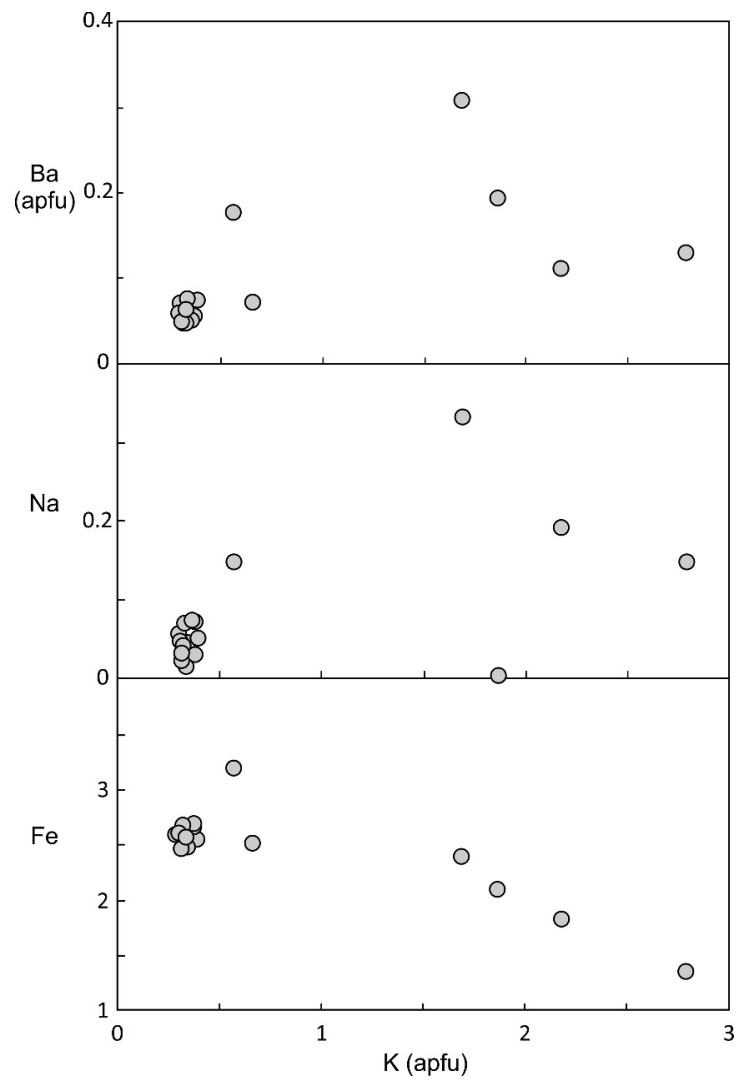

Figure 6. Binary $\mathrm{K}$ versus $\mathrm{Ba}, \mathrm{Na}$ and $\mathrm{Fe}$ (atoms per formula unit) for titanates from sample \#2.

phlogopite. Phlogopites from sample \#3 are strongly zoned with high $\mathrm{TiO}_{2}-\mathrm{FeO}_{\mathrm{T}}$ rims similar in composition to groundmass micas from the Leucite Hills lamproite and MARID xenoliths (Figure 4(a)). The ilmenite from these phlogopite-rich xenoliths has lower $\mathrm{Cr}_{2} \mathrm{O}_{3}$ and $\mathrm{MgO}$ contents (Figure 4(b)) if compared to ilmenite from sample \#2 (peridotite xenoliths). Prideritebearing ultramafic xenoliths from the Prairie Creek mica peridotite, Arkansas, show panidiomorphic texture and are considered as products of slow crystallization of a potassic (lamproitic) magma at high pressure subsequently fragmented and incorporated into the mica peridotite that carried them [11]. The phlogopite-rich xenoliths studied here do not show igneous texture, but the presence of priderite and the compositions of the associated minerals are taken as evidence of reaction with ultrapotassic melts. The chemical zoning of clinopyroxene and olivine and the overgrowth of compositionally different rims in the phlogopite indicate that equilibrium had not been achieved at the time of entrainment of the xenolith

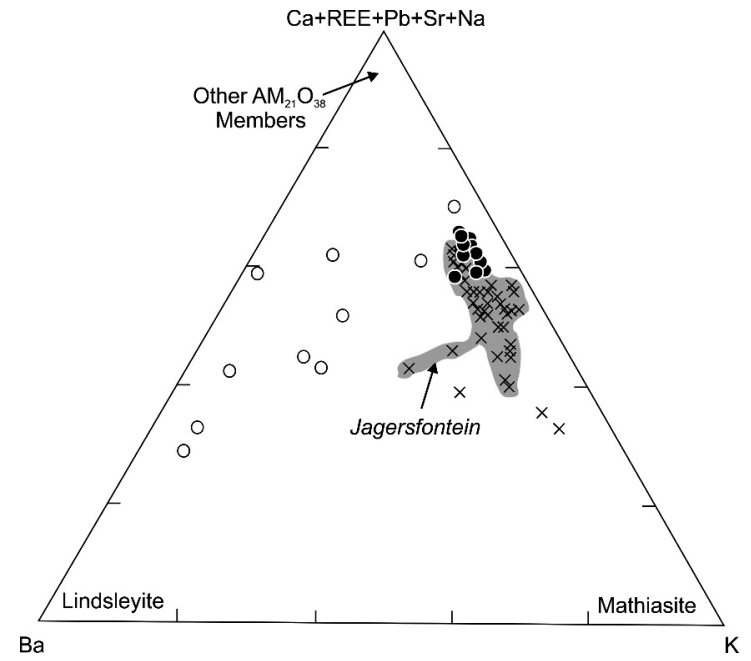

Figure 7. Triangular $\mathrm{Ba}-\mathrm{K}-(\mathrm{Ca}+\mathrm{Sr}+\mathrm{Na}+\mathrm{LREE}+\mathrm{Pb})$ diagram for titanates from sample \#2 (black circles) compared to the compositions of mathiasite (crosses) and lindsleyite (open circles) from South Africa (De Beers, Jagersfontein, Bultfontein and Kolonkwanen) $[9,55]$. Modified from [9]. $\mathrm{Pb}$ not analyzed in our samples.

in the host kimberlite. A similar interpretation was proposed by [47] for peridotite xenoliths from Lashaine Volcano, Northern Tanzania; according to this author, unequilibrated phases would not be preserved at the high temperatures of the upper mantle for a long time without annealing. This suggests that the metasomatic events leading to the formation of priderite and associated metasomatic phases in sample \#3 must have occurred shortly prior the entrainment of the xenoliths in the kimberlite melt. As in sample \#2, reaction with the host melt produced films of magnetite + perovskite along cracks and at the borders of the oxide minerals.

\subsection{Implications for the APIP magmatism}

The APIP is underlain by Neoarchean to Paleoproterozoic depleted lithospheric mantle of the São Francisco Craton modified by later metasomatic events. The enriched character of the APIP alkaline magmas is considered to reflect lithospheric mantle sources affected by metasomatism during Mesoproterozoic to Neoproterozoic events involved in the formation of the Brasília Fold Belt [15]. The finding that alkali-bearing $\mathrm{Ti}$ oxides are present in metasomatic mantle xenoliths indicates that the behavior of important incompatible trace-elements such as the LREE, $\mathrm{Ba}, \mathrm{Zr}, \mathrm{Nb}, \mathrm{Sr}$, and possibly also Th, $\mathrm{U}$ and $\mathrm{Pb}$ during mantle melting events may be controlled 

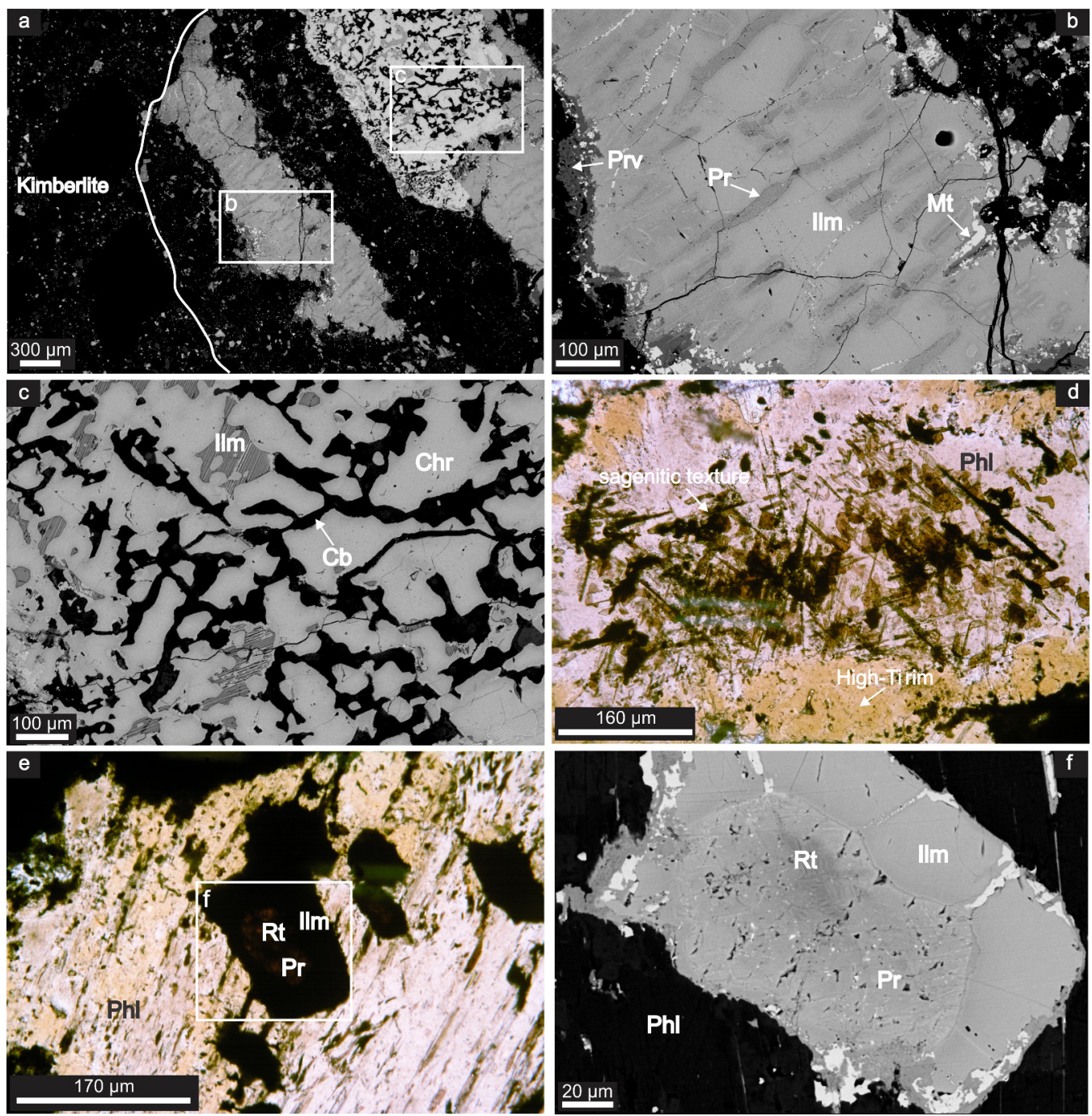

Figure 8. (a) BSE image showing ilmenite with lamellae and the symplectitic intergrowth; (b) BSE image of the priderite (Pr) lamellae within ilmenite (IIm). Note the magnetite (Mt) and perovskite (Prv) at the border; (c) BSE image of the symplectitic intergrowth between chromite (Chr), ilmenite (IIm) and calcite (Cb); (d) Transmitted-light photomicrograph of sagenitic phlogopite; (e) Transmitted-light photomicrograph of ilmenite surrounding priderite ( $\mathrm{Pr}$ )-rutile (Rt) intergrowth; (f) BSE image showing priderite-rutile intergrowth (darker areas) mantled by ilmenite in the area indicated in (e).

by these phases $[1,3]$. Additionally, the textural and chemical disequilibrium textures shown by the mineral assemblages where mathiasite and priderite occur may indicate that the metasomatic event(s) that generated these $\mathrm{Ti}$ oxides in lithospheric mantle occurred shortly prior to the entrainment of these xenoliths in the host magma that brought them to the surface (i.e., in the Cretaceous).

\section{Concluding remarks}

We report the first occurrences of mathiasite-loveringite and priderite in mantle xenoliths from the Alto Paranaíba Igneous Province. Mathiasite-loveringite is chemically similar (but with higher $\mathrm{Ca} / \mathrm{K}$ ) to mathiasite reported from the type area in Jagersfontein, Kaapval Craton, South Africa, and occurs as part of double reaction rim coronas surrounding chromite and ilmenite. Even though volumetrically minor, mathiasite-loveringite is 

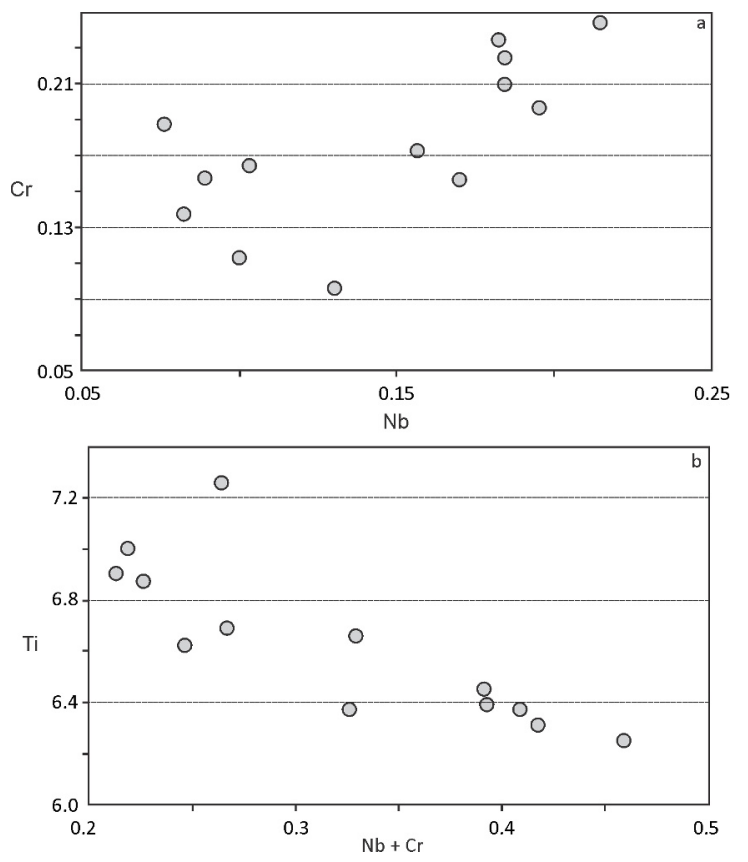

Figure 9. (a) Binary $\mathrm{Nb}$ versus $\mathrm{Cr}$; (b) Binary $(\mathrm{Nb}+\mathrm{Cr})$ versus Ti.

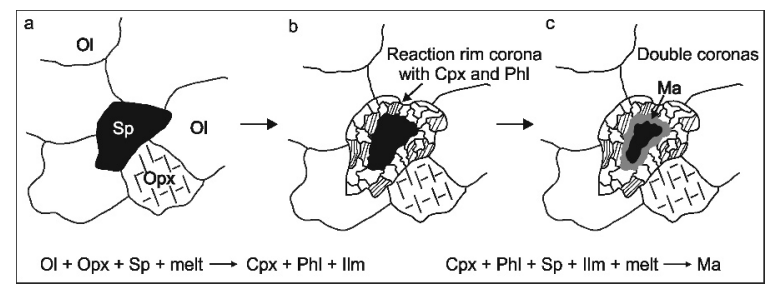

Figure 10. (a) Spinel (Sp), olivine (OI), and orthopyroxene (Opx) in a depleted peridotite; (b) Formation of clinopyroxene (Cpx)-phlogopite $(\mathrm{Phl})$ corona through reaction of a melt with the primary phases; (c) Formation of mathiasite in a double reaction rim corona surrounding the chromite located at the inner zone of the corona.

the main host of a large part of the incompatible trace elements present in the host xenolith, such as $\mathrm{Zr}$ and virtually all trace elements more incompatible than $\operatorname{Pr}$ (e.g., LREE, Ba, Nb; possibly also Th, U, $\mathrm{Pb})$, The chemical compositions of associated minerals are typical of metasomatic assemblages overprinted on previously depleted mantle (e.g., Al-poor clinopyroxene with fractionated REE patterns; $\mathrm{Mg}$ and $\mathrm{Cr}$-rich ilmenite; phlogopite plotting in the field of MARID).

Priderite occurs in a phlogopite-ilmenite rich xenolith in two textural varieties, both produced by reactions involving Mg-ilmenite and rutile: lens-like lamellae in ilmenite, and patchy zones replacing rutile and partially mantled by ilmenite. Electron microprobe analyses indicate that it corresponds to a high $\mathrm{K} / \mathrm{Ba}$ variety, and as such it is different from typical occurrences found in other mantle xenoliths and from alkaline igneous rocks such lamproites, carbonatites and kimberlites, which are richer in Ba. Associated minerals are chemically different from those found in the mathiasite-bearing xenoliths (Alpoor phlogopite, ilmenite with much lower $\mathrm{Cr}$ and $\mathrm{Mg}$ ), which may reflect a different (e.g., K-richer) metasomatic melt, possibly of ultrapotassic character, in line with the common occurrence of priderite in lamproitic rocks.

Disequilibrium textures and preservation of chemical zoning of associated minerals suggest that, notwithstanding the possibility that the metasomatic melts generating mathiasite-loveringite and priderite in the APIP are different, they record events of mantle enrichment that took place shortly prior to the entrainment of the xenoliths in the host kimberlite.

\section{Acknowledgements}

Financial support was provided by FAPESP (Fundação de Amparo á Pesquisa do Estado de São Paulo) through a Thematic Project Grant (2012/6082-6); our previous works on the APIP mantle xenoliths also benefited from grants \#2006/01925-4 and 2007/006355. We acknowledge with thanks contributions from Marcos Mansueto (Electron Microprobe Laboratory), Isaac Jamil Sayeg (Scanning Electron Microscope Laboratory), Sandra Andrade (LA-ICPMS Laboratory) and Prof. Lucelene Martins.

\section{References}

[1] Foley S., Höfer H., Brey G., High-pressure synthesis of priderite and members of the lindsleyite-mathiasite and hawthorneite-yimengite series, Contrib Mineral Petr, 117, 1994, 164-174

[2] Grégoire M., Lorand J. P., O’Reilly S. Y., Cottin J. Y., Armalcolite-bearing, Ti-rich metasomatic assemblages in harzburgitic xenoliths from the Kerguelen Islands: Implications for the oceanic mantle budget of high-field strength elements, Geochim Cosmochim Ac, 64, 2000, 673-694

[3] Konzett J., Yang H., Frost D. J., Phase relations and stability of magnetoplumbite- and crichtoniteseries phases under upper-mantle P-T conditions: 
an experimental study to 15GPa with implications for LILE metasomatism in the lithospheric mantle, J Petrol, 46, 2005, 749-781

[4] Sobolev N. V., Yefimova E. S., Kaminskiy F. V., Lavrientiev Y. G., Usova L. V., Titanate of complex composition and phlogopite in the diamond stability field. In: Composition and Processes of Deep-seated Zones of Continental Lithosphere, Novosibirsk: Nauka, 1988, 185-186

[5] Leost I., Stachel T., Brey G. P., Harris J. W., Ryabchikov I. D., Diamond formation and source carbonation: mineral associations in diamonds from Namibia, Contrib Mineral Petr, 145, 2003, 15-24

[6] Mitchell R. H., Bergman S. C., Petrology of Lamproites. Plenum Press, New York, 1991

[7] Le Maitre R. W., Igneous rocks: A classification and glossary of terms, 2nd edition, Cambridge University Press, 2002

[8] Haggerty S. E., The mineral chemistry of new titanates from the Jagersfontein kimberlite, South Africa: Implications for metasomatism in the upper mantle, Geochim Cosmochim Ac, 47, 1983, 1833-1854

[9] Haggerty S. E., Smyth J. R., Erlank A. J., Rickard R. S., Danchin R. V., Lindsleyite (Ba) and mathiasite (K): two new chromium-titanates in the crichtonite series from the upper mantle, Am Mineral, 68, 1983, 494505

[10] Lu Q., Zhou H. A., New progress in research on mathiasite in Mengying, Shandong-III. Oxide minerals containing the large ions $\mathrm{Cr}, \mathrm{Ti}$ and $\mathrm{Fe}$ in the upper mantle, Acta Mineralogica Sinica, 14, 1994, 343-347

[11] Mitchell R. H., Lewis R. D., Priderite-bearing xenoliths from the Prairie Creek mica peridotite, Arkansas, Can Mineral, 21(1), 1983, 59-64

[12] Velde D., Mineralogy of mafic xenoliths and their reaction zones in the olivine lamproite from Prairie Creek Arkansas and the paragenesis of haggertyite, $\mathrm{Ba}\left[\mathrm{Fe}_{6} \mathrm{Ti}_{5} \mathrm{Mg} \mathrm{O}_{19}\right.$, Am Mineral, 85, 2000, 420-429

[13] Gibson S. A., Thompson R .N., Leonardos O. H., Dickin A. P., Mitchell J. G., The Late Cretaceous impact of the Trindade mantle plume: Evidence from large-volume, mafic, potassic magmatism in SE Brazil, J Petrol, 36(1), 1995, 189-229

[14] Araujo A. L. N., Carlson R. W., Gaspar J. C., Bizzi L. A., Petrology of kamafugites and kimberlites from the Alto Paranaíba Alkaline Province, Minas Gerais, Brazil, Contrib Mineral Petr, 142(2), 2001, 163-177

[15] Carlson R. W., AraÃžjo A. L. N., Junqueira-Brod T. C., Gaspar J. C., Brod J. A., Petrinovic I. A., Hollanda M. H. B. M., Pimentel M. M., Sichel S., Chemical and isotopic relationships between peridotites xenoliths and mafic-ultrapotassic rocks from Southern Brazil, Chem Geol, 242, 2007, 415-434

[16] Guarino V., Wu F.-Y., Lustrino M., Melluso L., Brotzu P., Gomes C.B., Ruberti E., Tassinari C.C.G., Svisero D.P., U-Pb ages, $\mathrm{Sr}-\mathrm{Nd}$ isotope geochemistry, and petrogenesis of kimberlites, kamafugites and phlogopite-picrites of the Alto Paranaíba Igneous Province, Brazil, Chem Geol, 353, 2013, 65-82

[17] Pereira R. S., Fuck R., Archean nucleii and the distribution of kimberlite and related rocks in the São Francisco Craton, Brazil, Revista Brasileira de Geociências, 35(3), 2005, 93-104

[18] Pinto L. G. R., Interpretação de dados gravimétricos e eletromagnéticos do sul do cráton São Francisco: novos modelos crustais e litosféricos. PhD thesis, Instituto de Astronomia, Geofísica e Ciências Atmosféricas, Universidade de São Paulo, 2009 (in portuguese)

[19] VanDecar J. C., James D. E., Assumpção M., Seismic evidence for a fossil mantle plume beneath South America and implications for plate driving forces, Nature, 378(6552), 1995, 25-31

[20] Rocha M. P., Schimmel M., Assumpção M., Uppermantle seismic structure beneath SE and Central Brazil from $\mathrm{P}$ - and $\mathrm{S}$-wave regional traveltime tomography, Geophys J Int, 184(1), 2011, 268-286

[21] Meyer H. O. A., Svisero D. P., Mantle xenoliths in South America. In: Nixon P.H. Mantle Xenoliths, John Wiley \& Sons, New York, 1987, 844

[22] Meyer H. O. A., Svisero D. P., Limeira and Indaiá intrusions, Minas Gerais. In: Field Guide Book, 5th International Kimberlite Conference, Araxá (Minas Gerais, Brazil), CPRM Special Publication, 1991, 4955

[23] Meyer H. O. A., Garwood B. L., Svisero D. P., Smith C. B., Alkaline Ultrabasic Intrusions of Western Minas Gerais, Brazil. In: Meyer H. O. A., Leonardos O. $\mathrm{H}$., Proceedings of the 5 th International Kimberlite Conference, CPRM/DNPM Special Publication, 1, 1994, 140-155

[24] Mercier J. C. C., Nicolas A., Textures and fabrics of upper mantle peridotites as illustrated by xenoliths from basalts, J Petrol, 16, 1975, 454-487

[25] Bastin G. F., Van Loo F. J. J., Heijiligers H. J. M., Evaluation and use of gaussian $(\phi(p z))$ curves in quantitative electron probe microanalysis: a new optimization, X-ray Spectrom, 13, 1984, 91-97

[26] Haggerty S. E., The chemistry and genesis of opaque minerals in kimberlites, Phys Chem Earth, 9, 1975, 295-307

[27] Jianxiong Z., Guiojie Y., Jianhong Z., Mathiasite in a kimberlite from China, Acta Mineralogica Sinica, 9, 
1984, 193-200

[28] Campbell I. H., Kelly P. R., The geochemistry of loveringite, a uranium-rare-earth-bearing accessory phase from the Jimberlana Intrusion of Western Australia, Mineral Mag, 42(322), 1978, 187-193

[29] Qi L., Huyun Z., A new progress in research on mathiasite in Mengying, Snadong, III. Oxide minerals containing the large ions $\mathrm{Cr}, \mathrm{Ti}$ and $\mathrm{Fe}$ in the upper mantle, Acta Mineralogica Sinica 4, 1994, 4

[30] Witt-Eickshen G. E., Seck H. A. Solubility of Ca and $\mathrm{Al}$ in orthopyroxene from spinel peridotite: an improved version of an empirical geothermometer, Contrib Mineral Petr, 106, 1991, 431-439

[31] Dawson J. B., Smith J. V., The MARID (micaamphibole-rutile-ilmenite-diopside) suite of xenoliths in kimberlite, Geochim Cosmochim Ac, 41, 1977, 309323

[32] Costa V. S., Figueiredo B. R., Weska R. K., Estudos mineralógicos e químicos do kimberlito Batovi 6, MT, em comparação com as intrusões Três Ranchos 4, GO e Limeira 1, MG, Geochimica Brasiliensis, 11(1), 1997, 53-71 (in portuguese)

[33] Haggerty S. E., Upper mantle mineralogy, J Geodyn, 20, 1995, 331-364

[34] Barkov A. Y., Fleet M. E., Martin R. F., Men'Shikov Y. P., Sr-Na-REE titanates of the crichtonite group from a fenitized megaxenolith, Khibina alkaline complex, Kola Peninsula, Russia: first occurrence and implications, Eur J Mineral, 18(4), 2006, 493-502

[35] Gatehouse B. M., Grey I. E., Smyth J. R., Structure refinement of mathiasite, $(\mathrm{K} 0.62 \mathrm{Na} 0.14 \mathrm{Ba} 0.14 \mathrm{Sr} 0.10)$ [Sigma]1.0[Ti12.90Cr3.10Mg1.53Fe2.15Zr0.67Ca0.29 $(\mathrm{V}, \mathrm{Nb}, \mathrm{Al}) 0.36]$ [Sigma]21.0038, Acta Crystallogr C, 39(4), 1983, 421-422

[36] Biagioni C., Capalbo C., Pasero M., Nomenclature tunings in the hollandite supergroup, Eur J Mineral, 25(1), 2013, 85-90

[37] Norrish K., Priderite, a new mineral from the leucitelamproites of the west Kimberley area, Western Australia, Mineral Mag, 29, 1951, 496-501

[38] Gaspar J. C., Conceicao e Silva A. J. G., de Araujo D. P., Composition of priderite in phlogopites from the Catalao I carbonatite complex, Brazil, Mineral Mag, 58(3), 1994, 409-415

[39] Middlemost E. A. K., Paul D. K., Fletcher I. R., Geochemistry and mineralogy of the minettelamproite association from the Indian Gondwanas, Lithos, 22(1), 1988, 31-42

[40] Mitchell R. H., Meyer H. O. A., Niobian K-Ba$V$ titanates from micaceous kimberlite, Star mine, Orange Free State, South Africa, Mineral Mag, 53, 1989, 451-456
[41] Mitchell R. H., Kimberlites, orangeites and related rocks. Plenum Press, New York, 1995, 410

[42] Rao N. V. C., Sinha A. K., Kumar S., Srivastava R., K., K-rich titanate from the Jharia ultrapotassic rock, Gondwana Coal Fields, Eastern India, and its petrological significance, Journal Geological Society of India, 81, 2013, 733-736

[43] Xiao Y., Zhang H. -F., Fan W. -M., Ying J. -F., Zhang J., Zhao X. -M., Su B. -X., Evolution of lithospheric mantle beneath the Tan-Lu fault zone, eastern North China Craton: Evidence from petrology and geochemistry of peridotite xenoliths, Lithos, 117, 2010, 229-246

[44] Matson D. W., Muenow D. W., Garcia M. O., Volatile contents of phlogopite micas from South African kimberlite, Contrib Mineral Petr, 93, 1986, 399-408

[45] Simon N. S. C., Irvine G. J., Davies G. R., Pearson D. G., Carlson R. W., The origin of garnet and clinopyroxene in "depleted" Kaapvaal peridotites, Lithos, 71, 2003, 289-322

[46] Bianchini G., Beccaluva L., Bonadiman C., Nowell G., Pearson G., Siena F., Wilson M., Evidence of diverse depletion and metasomatic events in harzburgitelherzolite mantle xenoliths from the Iberian plate (Olot, NE Spain): Implications for lithosphere accretionary processes, Lithos, 94, 2007, 25-45

[47] Dawson J. B., Metasomatism and partial melting in upper-mantle peridotite xenoliths from the Lashaine Volcano, Northern Tanzania, J Petrol, 43, 2002, 17491777

[48] Alkmim F. F., Brito-Neves B. B., Castro Alves J. A., Tectonic framework of the São Francisco Craton. In: Domingues J. M. L., Misi A. The São Francisco Craton, Sociedade Brasileira de Geologia, Salvador, 1993, 45-62 (in portuguese)

[49] Smith J. V., Breenessholtz R., Dawson J. B., Chemistry of micas from kimberlites and xenoliths 1. Micaceous kimberlites, Geochim Cosmochim Ac, 42, 1978, 959971

[50] Jaques A. L., Lewis J. D., Smith C. B., The kimberlites and lamproites of western Australia, Geological Survey of Western Australia, Bulletin, 132, 1986, 268

[51] Scott-Smith B. H., Skinner E. M. W., Loney P. E., The Kapamba lamproites of the Luangwa Valley, Eastern Zambia. In: Ross J., Proceedings of the 4th International Kimberlite Conference, Geological Society of Australia Special Publication, Perth, 1, 1989, 189-205

[52] Melluso L., Lustrino M., Ruberti E., Brotzu P., Gomes C. B., Morbidelli L., Morra V., Svisero D., D'Amelio F., Major- and trace-element composition of olivine, perovskite, clinopyroxene, $\mathrm{Cr}-\mathrm{Fe}-\mathrm{Ti}$ oxides, 
phlogopite and host kamafugites and kimberlites, Alto Paranaíba, Brazil, Can Mineral, 46, 2008, 19-40

[53] McDonough W. F., Sun S. -s., Composition of the Earth, Chem Geol, 120, 1995, 223-253

[54] Sun S. -s., McDonough W. F., Chemical and isotopic systematics of oceanic basalts: implications for mantle composition and processes. Magmatism in the Ocean Basins, Geol Soc Spec Publ, 42, 1989, 313345
[55] Jones A. P., Smith J. V., Dawson J. B., Mantle metasomatism in 14 veined peridotites from the Bultfontein Mine, South Africa, J Geol, 90, 1982, 435453

[56] Carmichael I. S. E., The iron-titanium oxides of salic volcanic rocks and their associated ferromagnesian silicates, Contrib Mineral Petr, 14, 1967, 36-64 